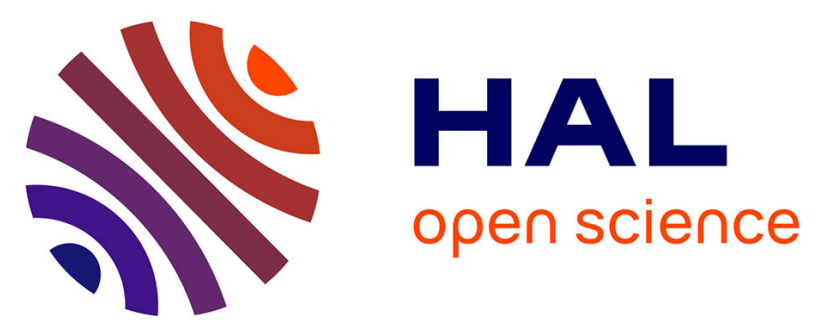

\title{
Variability in the sensitivity among model simulations of permafrost and carbon dynamics in the permafrost region between 1960 and 2009
}

\author{
A.D. Mcguire, C. Koven, D.M. Lawrence, J.S. Clein, J. Xia, C. Beer, E. \\ Burke, G. Chen, X. Chen, C. Delire, et al.
}

\section{To cite this version:}

A.D. Mcguire, C. Koven, D.M. Lawrence, J.S. Clein, J. Xia, et al.. Variability in the sensitivity among model simulations of permafrost and carbon dynamics in the permafrost region between 1960 and 2009 . Global Biogeochemical Cycles, 2016, 30 (7), pp.1015-1037. 10.1002/2016GB005405 . hal-02605430

\section{HAL Id: hal-02605430 \\ https://hal.inrae.fr/hal-02605430}

Submitted on 28 Oct 2020

HAL is a multi-disciplinary open access archive for the deposit and dissemination of scientific research documents, whether they are published or not. The documents may come from teaching and research institutions in France or abroad, or from public or private research centers.
L'archive ouverte pluridisciplinaire HAL, est destinée au dépôt et à la diffusion de documents scientifiques de niveau recherche, publiés ou non, émanant des établissements d'enseignement et de recherche français ou étrangers, des laboratoires publics ou privés. 
University of Lapland

This is a self-archived version of an original article. This version usually differs somewhat from the publisher's final version, if the self-archived version is the accepted author manuscript.

\section{Variability in the sensitivity among model simulations of permafrost and carbon dynamics in the permafrost region between 1960 and 2009}

McGuire, A. David; Koven, Charles; Lawrence, David M.; Clein, Joy S.; Xia, Jiangyang; Beer, Christian; Burke, Eleanor; Chen, Guangsheng; Chen, Xiaodong; Delire, Christine; Jafarov, Elchin; MacDougall, Andrew H.; Marchenko, Sergey; Nicolsky, Dmitry; Peng, Shushi; Rinke, Annette; Saito, Kazuyuki; Zhang, Wenxin; Alkama, Ramdane; Bohn, Theodore J.; Ciais, Philippe; Decharme, Bertrand; Ekici, Altug; Gouttevin, Isabelle; Hajima, Tomohiro; Hayes, Daniel J.; Ji, Duoying; Krinner, Gerhard; Lettenmaier, Dennis P.; Luo, Yiqi; Miller, Paul A.; Moore, John C.; Romanovsky, Vladimir; Schädel, Christina; Schaefer, Kevin; Schuur, Edward A.G.; Smith, Benjamin; Sueyoshi, Tetsuo; Zhuang, Qianlai

Published in:

GLOBAL BIOGEOCHEMICAL CYCLES

DOI:

10.1002/2016GB005405

Published: 01.01 .2016

Document Version

Publisher's PDF, also known as Version of record

Citation for pulished version (APA):

McGuire, A. D., Koven, C., Lawrence, D. M., Clein, J. S., Xia, J., Beer, C., Burke, E., Chen, G., Chen, X., Delire, C., Jafarov, E., MacDougall, A. H., Marchenko, S., Nicolsky, D., Peng, S., Rinke, A., Saito, K., Zhang, W., Alkama, R., ... Zhuang, Q. (2016). Variability in the sensitivity among model simulations of permafrost and carbon dynamics in the permafrost region between 1960 and 2009. GLOBAL BIOGEOCHEMICAL CYCLES, 30(7), 1015-1037. https://doi.org/10.1002/2016GB005405 


\section{Global Biogeochemical Cycles}

\section{RESEARCH ARTICLE}

10.1002/2016GB005405

\section{Key Points:}

- Models estimate a loss of near-surface permafrost area in the Northern Hemisphere between 1960 and 2009

- Models estimate that both vegetation and soil $\mathrm{C}$ have increased in the permafrost region

- Simulated increases in gross primary production are primarily responsible for the modeled increases in C storage

Supporting Information:

- Figures S1-S6

\section{Correspondence to:}

A. D. McGuire,

admcguire@alaska.edu

\section{Citation:}

McGuire, A. D., et al. (2016), Variability in the sensitivity among model simulations of permafrost and carbon dynamics in the permafrost region between 1960 and 2009, Global Biogeochem. Cycles, 30, 1015-1037, doi:10.1002/2016GB005405.

Received 2 MAR 2016 Accepted 12 JUN 2016 Accepted article online 15 JUN 2016 Published online 8 JUL 2016

\section{Variability in the sensitivity among model simulations of permafrost and carbon dynamics in the permafrost region between 1960 and 2009}

\begin{abstract}
A. David McGuire ${ }^{1}$, Charles Koven ${ }^{2}$, David M. Lawrence ${ }^{3}$, Joy S. Clein ${ }^{4}$, Jiangyang Xia ${ }^{5}$, Christian Beer ${ }^{6}$, Eleanor Burke ${ }^{7}$, Guangsheng Chen ${ }^{8}$, Xiaodong Chen ${ }^{9}$, Christine Delire ${ }^{10}$, Elchin Jafarov ${ }^{11}$, Andrew H. MacDougall ${ }^{12}$, Sergey Marchenko ${ }^{13}$, Dmitry Nicolsky ${ }^{13}$, Shushi Peng ${ }^{14,15}$, Annette Rinke ${ }^{16,17}$, Kazuyuki Saito ${ }^{18}$, Wenxin Zhang ${ }^{19}$, Ramdane Alkama ${ }^{10}$, Theodore J. Bohn ${ }^{20}$, Philippe Ciais $^{14}$, Bertrand Decharme ${ }^{10}$, Altug Ekici ${ }^{6}$, Isabelle Gouttevin ${ }^{15,21}$, Tomohiro Hajima ${ }^{18}$, Daniel J. Hayes ${ }^{8}$, Duoying Ji ${ }^{17}$, Gerhard Krinner ${ }^{15}$, Dennis P. Lettenmaier ${ }^{22}$, Yiqi Luo ${ }^{23}$, Paul A. Miller ${ }^{19}$, John C. Moore ${ }^{17}$, Vladimir Romanovsky ${ }^{13}$, Christina Schädel ${ }^{24}$, Kevin Schaefer ${ }^{25}$, Edward A.G. Schuur ${ }^{24}$, Benjamin Smith ${ }^{19}$, Tetsuo Sueyoshi ${ }^{18}$, and Qianlai Zhuang ${ }^{26}$

${ }^{1}$ U.S. Geological Survey, Alaska Cooperative Fish and Wildlife Research Unit, University of Alaska Fairbanks, Fairbanks, Alaska, USA, ${ }^{2}$ Lawrence Berkeley National Laboratory, Berkeley, California, USA, ${ }^{3}$ National Center for Atmospheric Research, Boulder, Colorado, USA, ${ }^{4}$ Institute of Arctic Biology, University of Alaska Fairbanks, Fairbanks, Alaska, USA, ${ }^{5}$ Tiantong National Station of Forest Ecosystem, School of Ecological and Environmental Sciences, East China Normal University, Shanghai, China, ${ }^{6}$ Department of Environmental Science and Analytical Chemistry (ACES) and Bolin Centre for Climate Research, Stockholm University, Stockholm, Sweden, ${ }^{7}$ Met Office Hadley Centre, Exeter, UK, ${ }^{8}$ Environmental Sciences Division, Oak Ridge National Laboratory, Oak RidgeTennessee, USA, ${ }^{9}$ Department of Civil and Environmental Engineering, University of Washington, Seattle, Washington, USA, ${ }^{10} \mathrm{GAME}$, Unité Mixte de Recherche CNRS/Meteo-France (UMR 3589), Toulouse CEDEX, France, ${ }^{11}$ Institute of Arctic Alpine Research, University of Colorado Boulder, Boulder, Colorado, USA, ${ }^{12}$ School of Earth and Ocean Sciences, University of Victoria, Victoria, British Columbia, Canada, ${ }^{13}$ Geophysical Institute, University of Alaska Fairbanks, Fairbanks, Alaska, USA, ${ }^{14}$ Laboratoire des Sciences du Climat et de l'Environnement, CEA-CNRS-UVSQ, UMR 8212, Gif-sur-Yvette, France, ${ }^{15}$ Universite-Grenoble Alpes/CNRS, Laboratoire de Glaciologie et Géophysique de I'Environnement (LGGE), UMR 5183, BP53, Grenoble, France, ${ }^{16}$ Alfred Wegener Institute Helmholtz Centre for Polar and Marine Research, Potsdam, Germany, ${ }^{17}$ State Key Laboratory of Earth Surface Processes and Resource Ecology, College of Global Change and Earth System Science, Beijing Normal University, Beijing, China, ${ }^{18}$ Department of Integrated Climate Change Projection Research, Japan Agency for Marine-Earth Science and Technology, Yokohama, Japan,

${ }^{19}$ Department of Physical Geography and Ecosystem Science, Lund University, Lund, Sweden, ${ }^{20}$ School of Earth and Space Exploration, Arizona State University, Tempe, Arizona, USA, ${ }^{21}$ Irstea, UR HHLY, 5 rue de la Doua, CS 70077, Villeurbanne CEDEX, France, ${ }^{22}$ Department of Geography, University of California, Los Angeles, California, USA, ${ }^{23}$ Department of Microbiology and Plant Biology, University of Oklahoma, Norman, Oklahoma, USA, ${ }^{24}$ Center for Ecosystem Science and Society and Department of Biological Sciences, Northern Arizona University, Flagstaff, Arizona, USA, ${ }^{25}$ National Snow and Ice Data Center, University of Colorado Boulder, Boulder, Colorado, USA, ${ }^{26}$ Purdue University, West Lafayette, Indiana, USA
\end{abstract}

Abstract A significant portion of the large amount of carbon $(C)$ currently stored in soils of the permafrost region in the Northern Hemisphere has the potential to be emitted as the greenhouse gases $\mathrm{CO}_{2}$ and $\mathrm{CH}_{4}$ under a warmer climate. In this study we evaluated the variability in the sensitivity of permafrost and $\mathrm{C}$ in recent decades among land surface model simulations over the permafrost region between 1960 and 2009. The 15 model simulations all predict a loss of near-surface permafrost (within $3 \mathrm{~m}$ ) area over the region, but there are large differences in the magnitude of the simulated rates of loss among the models ( 0.2 to $\left.58.8 \times 10^{3} \mathrm{~km}^{2} \mathrm{yr}^{-1}\right)$. Sensitivity simulations indicated that changes in air temperature largely explained changes in permafrost area, although interactions among changes in other environmental variables also played a role. All of the models indicate that both vegetation and soil $\mathrm{C}$ storage together have increased by 156 to $954 \mathrm{TgC} \mathrm{yr}^{-1}$ between 1960 and 2009 over the permafrost region even though model analyses indicate that warming alone would decrease soil $C$ storage. Increases in gross primary production (GPP) largely explain the simulated increases in vegetation and soil C. The sensitivity of GPP to increases in atmospheric $\mathrm{CO}_{2}$ was the dominant cause of increases in GPP across the models, but comparison of simulated GPP trends across the 1982-2009 period with that of a global GPP data set indicates that all of the models overestimate the trend in GPP. Disturbance also appears to be an important factor affecting C storage, as models that consider disturbance had lower increases in C storage than models that did not consider disturbance. To improve the modeling of $C$ in the permafrost region, there is the need for the 
modeling community to standardize structural representation of permafrost and carbon dynamics among models that are used to evaluate the permafrost $C$ feedback and for the modeling and observational communities to jointly develop data sets and methodologies to more effectively benchmark models.

\section{Introduction}

A significant portion of the large amount of carbon (C) currently stored in soils of the permafrost region in the Northern Hemisphere (1330 to $1580 \mathrm{PgC}$ [Schuur et al., 2015]) has the potential to be emitted as greenhouse gases in the form of both $\mathrm{CO}_{2}$ and $\mathrm{CH}_{4}$ under a warmer climate [Schuur et al., 2008, 2011, 2013, 2015; Chapin et al., 2008; McGuire et al., 2009; Schaefer et al., 2011; Koven et al., 2011; Zhuang et al., 2015]. The degree to which responses of terrestrial ecosystems in the Northern Hemisphere permafrost region tend to amplify or mitigate global warming depends on a number of processes affecting the $C$ cycle in these ecosystems. The fate of soil $C$ of ecosystems within the permafrost region in response to climate change depends in part on processes related to decomposition including the quantity of $\mathrm{C}$ in both the active layer and permafrost, the rate of permafrost thaw, the lability of soil $C$ in thawed permafrost, and whether the fate of soil $C$ is affected by aerobic or anaerobic decomposition processes [Schuur et al., 2008, 2015]. However, soil C may be replenished at a faster rate than losses if the response of vegetation $\mathrm{C}$ and plant tissue turnover and mortality to climate change and increases in atmospheric $\mathrm{CO}_{2}$ compensates for decomposition losses. In addition, disturbances, such as fire, have the potential to release substantial quantities of $C$ from both vegetation and soils in permafrost ecosystems [McGuire et al., 2010a; Hayes et al., 2011; Mack et al., 2011; Genet et al., 2013]. Several analyses project an increase in the frequency and severity of fire in response to climate change in the boreal forest [Flannigan et al., 1998; Balshi et al., 2009], which has consequences not only for the direct combustion of soil $\mathrm{C}$ but also for the decomposition of $\mathrm{C}$ in permafrost soils as fire disturbance can accelerate subsequent thaw of permafrost by removing the insulating soil organic horizon [Jafarov et al., 2013].

Terrestrial ecosystems of the northern permafrost region have accumulated soil $\mathrm{C}$ for millennia during the Holocene [Harden et al., 1992; Schirrmeister et al., 2002; Zimov et al., 2006]. In recent decades, the northern permafrost region has experienced double the rate of warming as the rest of the Earth [Serreze and Francis, 2006; Fyfe et al., 2013; Pithan and Mauritsen, 2014]. A key question is whether the recent warming and projected additional warming will result in the net loss of soil $C$ from ecosystems of the permafrost region. Assessments have estimated that these ecosystems have been an uncertain sink of $C$ from the atmosphere of between 0 and $0.8 \mathrm{Pg} C$ per year in recent decades [McGuire et al., 2009]. Separate assessments of $C$ balance have been conducted for arctic tundra [McGuire et al., 2012] and the boreal forest [Pan et al., 2011] in the 1990s and 2000s. Syntheses of flux observations and inversion models indicate that the annual exchange of $\mathrm{CO}_{2}$ between arctic tundra and the atmosphere has large uncertainties that cannot be distinguished from neutral balance [McGuire et al., 2012]. However, one synthesis of flux observations suggests that winter losses of $\mathrm{CO}_{2}$ to the atmosphere from Arctic tundra may be greater than summer uptake, although data are scarce in winter [Belshe et al., 2013]. In contrast, the mean estimate from an ensemble of process-based model simulations suggests that arctic tundra acted as a sink for atmospheric $\mathrm{CO}_{2}$ in recent decades, but based on the uncertainty among estimates it cannot be determined with confidence whether tundra ecosystems represent a weak or a strong sink [McGuire et al., 2012].

Analyses of forest inventory data presented in Pan et al. [2011] indicate that the boreal forest was a sink for atmospheric $\mathrm{CO}_{2}$ of $0.5 \pm 0.08 \mathrm{Pg} \mathrm{Cyr}^{-1}$ in both the $1990 \mathrm{~s}$ and $2000 \mathrm{~s}$ and that most of this $\mathrm{C}$ was being stored as increases in dead wood, litter, and soil C pools in Russia. In contrast, analyses among process-based models applied across Russia indicate a much weaker sink of approximately $0.1 \mathrm{Pg} \mathrm{Cyr}^{-1}$ [Dolman et al., 2012], which has been attributed to higher soil $\mathrm{C}$ decomposition rates in process-based models than in inventory models [Dolman et al., 2012]. In addition, one process-based analysis that considers fire indicates that the boreal forest $C$ sink may be weakening because of the loss of soil $C$ associated with fire disturbance [Hayes et al., 2011] and the exposure of newly thawed permafrost soil C to decomposition [Hayes et al., 2014]. Thus, a key unresolved issue is whether warming in recent decades has resulted in the accumulation or the loss of soil $C$ from ecosystems in the permafrost region of the Northern Hemisphere.

In this study we evaluate the variability in the sensitivity of the dynamics of permafrost and carbon in the permafrost region in recent decades among simulations of participating models of the model integration group of the Permafrost Carbon Network (http://www.permafrostcarbon.org). Because there has already 


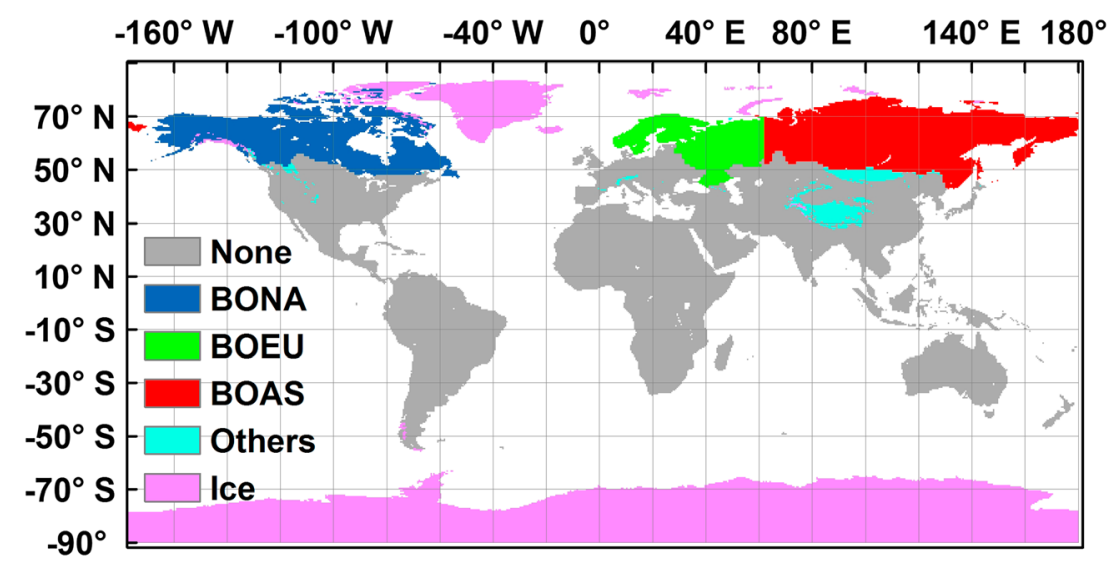

Figure 1. The spatial extent of the permafrost region in the Northern Hemisphere defined in this study. Subregions include boreal Asia (BOAS), boreal Europe (BOEU), boreal North America (BONA), glaciers and ice sheets (ice), and other permafrost areas (other).

been substantial warming in the permafrost region over the last half century, a retrospective analysis over this time period has the potential to better understand the sensitivity of $C$ simulated by process-based models as a first step toward reducing uncertainties among the models and improving future projections of the permafrost climate feedback by models. Our key questions in this evaluation are (1) what is the variability in the loss of near-surface permafrost since 1960 among model simulations? (2) what is the variability in changes of $C$ stored in the permafrost region since 1960 among model simulations? and (3) what factors explain variability in the simulated dynamics of permafrost and permafrost $C$ pools among the models? In process-based models, these dynamics depend on the climate forcing used to drive the models as well as various factors in the models that influence their sensitivity to climate variability and change. The variability in the sensitivity of the models is important to understand because the changes in different drivers can cause different responses. For example, the loss of insulation from low winter snow will enhance the persistence of permafrost while summer warming will promote the loss of permafrost, given all other things equal. With respect to carbon dynamics, carbon assimilation will generally be enhanced by increases in atmospheric $\mathrm{CO}_{2}$ and longer growing seasons but will be reduced by drought conditions. Climate warming is expected to enhance decomposition losses from thawing soils of the permafrost region, but whether this is greater than possible enhancements in assimilation in recent decades is not clear. These examples indicate that it is important to understand factors that influence sensitivity, which include structural representation (i.e., which processes are considered), mathematical formulation representation (i.e., how processes are mathematically described), and parameterization (i.e., how values of parameters in formulations are specified) embodied in the models. In this study, we primarily focus on analyzing the variability in the sensitivity of permafrost and permafrost C pools, as represented in models, to changing climate since 1960 with respect to differences in climate forcing and differences in which processes they do or do not consider. Although our evaluation here is primarily focused on analysis of variability in the sensitivity of the models as a first step toward reducing uncertainties, more detailed evaluations of processes are being conducted in other studies of the simulation results presented in this study (see Discussion). We also provide thoughts on next steps toward reducing uncertainties (see Conclusions).

\section{Methods}

\subsection{Spatial Extent of Simulations}

The spatial domain of the permafrost region in the Northern Hemisphere that we considered in this study $\left(30.88 \times 10^{6} \mathrm{~km}^{2}\right.$; Figure 1) was defined based on (1) the location of glaciers and ice sheets in the Northern Hemisphere; (2) the extent of the boreal Asia, boreal Europe, and boreal North America regions identified in Hayes et al. [2011]; and (3) other permafrost areas outside of these areas identified as part of the permafrost domain in the permafrost and ground ice condition map of Brown et al. [1998]. The models in this study did not simulate permafrost and $\mathrm{C}$ dynamics for glacier and ice sheet area. The areas of boreal Asia, Europe, and 
North America facilitate comparisons with inversion model analyses of the C cycle. The other area in the comparison includes permafrost of Tibet and various mountain ranges in the North Hemisphere as well as areas just south of boreal Asia that are considered part of the permafrost region by Brown et al. [1998].

\subsection{Permafrost and Carbon Cycle Variables Analyzed in This Study}

Our analysis of the variability in the sensitivity of simulated permafrost dynamics focuses on changes in nearsurface permafrost area and changes in mean annual soil temperature at $20 \mathrm{~cm}$ depth since 1960 . While there are many different ways to define and estimate the presence of near-surface permafrost [Wang et al., 2016], we operationally define the area of near-surface permafrost in this study as the area simulated in which the maximum seasonal active layer thickness (ALT) is less than $3 \mathrm{~m}$, where the bulk of the frozen $C$ is located. We chose to analyze the annual mean soil temperature at $20 \mathrm{~cm}$ depth as the temperature at this depth is relevant for near-surface soil biogeochemical processes.

Our analysis of the variability in the sensitivity of $C$ focuses on changes in soil $C$, vegetation $C$, and ecosystem C since 1960. Soil $C$ is an aggregated variable that is the sum of estimates for litter C, organic horizon C, mineral soil C, coarse woody debris, land use pools (e.g., wood and agricultural products), and soil $C$ exudates reported by some models. Vegetation $C$ is the sum of any live vegetation pool and typically includes leaves, stems, and root $C$. Ecosystem $C$ is the sum of the aggregated soil and vegetation $C$ pools.

In this study, the C cycle fluxes we analyzed generally follow the C cycle terminology of Chapin et al. [2006]; see also McGuire et al. [2010a, 2012] and Hayes et al. [2011] for the application of this terminology in largescale studies. The advantage of using this terminology in comparison with other terminologies such as the net biome production terminology of Schulze and Heimann [1998] is that the Chapin et al. [2006] terminology does not depend on spatial scale.

The fluxes we considered in this study include net primary production (NPP), heterotrophic respiration (RH), fire emissions (fire $\mathrm{C}$ ), biogenic $\mathrm{CH}_{4}$ emissions ( $\mathrm{BIO} \mathrm{C}-\mathrm{CH}_{4}$ ), and lateral $\mathrm{C}$ fluxes. Net primary production is the net uptake of $\mathrm{CO}_{2}$ by vegetation and represents the difference between photosynthetic uptake and plant respiration. $\mathrm{RH}$ is the release of $\mathrm{CO}_{2}$ to the atmosphere associated with decomposition of dead organic matter. Fire $\mathrm{C}$ is the release of $\mathrm{C}$-related compounds to the atmosphere from the combustion of aboveground and belowground $\mathrm{C}$ pools during fire. We assumed that all of fire $\mathrm{C}$ is $\mathrm{CO}_{2}$ since the models did not distinguish among species of $\mathrm{C}$ emitted such as $\mathrm{CO}_{2}, \mathrm{CO}$, and pyrogenic $\mathrm{CH}_{4}$. $\mathrm{BIO} \mathrm{C}-\mathrm{CH}_{4}$ represents biogenic $\mathrm{CH}_{4}$ emissions to the atmosphere from the production of methane by methanogenic organisms in the soil minus any uptake in the soil column by methanotrophic organisms. In general, the models in this study do not explicitly consider the $\mathrm{CH}_{4}$ emissions from lakes in the permafrost region, although their definition of the spatial extent of wetlands may include lakes. Lateral $C$ includes any lateral losses of $C$ from the ecosystem $C$ pools that we do not directly estimate in the balance with the atmosphere, and includes the lateral transfer of harvest products from agricultural, forestry, and land use, and C fluxes to aquatic ecosystems such as dissolved organic $C$. Note that some proportion of lateral $C$ is returned to that atmosphere at the regional scale, but the models in this study do not estimate that proportion.

There are also three fluxes in our accounting that represent combinations of other fluxes that we consider: net ecosystem production (NEP), net ecosystem exchange (NEE), and net ecosystem carbon balance (NECB). NEP is defined as NPP - RH, NEE represents net $\mathrm{CO}_{2}$ exchange with the atmosphere and is defined as fire C - NEP, and NECB is defined as NPP - RH - fire C - BIO C-CH4 - lateral C [see Chapin et al., 2006]. For NEP and NECB, we follow the ecosystem ecology sign convention in which a positive sign indicates a sink of $C$ into the ecosystem, whereas the quantity NEE follows the atmosphere sign convention in which a negative sign indicates a sink of $C$ into the ecosystem from the atmosphere.

\subsection{Models Compared in This Study}

In this study we compare the permafrost and C dynamics of the permafrost region between 1960 and 2009 among models that have focused on representing processes in ecosystems underlain by permafrost. The 15 sets of model simulations compared in this study include those from (1) the Community Land Model (CLM version 4.5) [Oleson et al., 2013; Koven et al., 2013a], (2) the Common Land Model [Dai et al., 2003, 2004; Ji et al., 2014], (3) two versions of the Geophysical Institute Permafrost Lab model (GIPLa [Marchenko et al., 2008] and GIPLb [Nicolsky et al., 2009]), (4) the Interaction Sol-Biosphere-Atmosphere (ISBA) land model 
Table 1. Comparison of Conceptual Representation of Permafrost Dynamics Among Models

\begin{tabular}{|c|c|c|c|c|c|c|}
\hline Model & $\begin{array}{c}\text { Approach to Modeling Soil Thermal } \\
\text { Dynamics }\end{array}$ & Depth & $\begin{array}{l}\text { Moss } \\
\text { Insulation } \\
\text { Considered }\end{array}$ & $\begin{array}{l}\text { Organic Soil } \\
\text { Insulation } \\
\text { Considered }\end{array}$ & $\begin{array}{c}\text { Snow } \\
\text { Insulation } \\
\text { Considered }\end{array}$ & $\begin{array}{c}\text { Effect of Unfrozen } \\
\text { Water on Phase Change } \\
\text { Considered }^{a, b}\end{array}$ \\
\hline CLM4.5 & Multilayer finite difference heat diffusion & $45.1 \mathrm{~m}$ & No & $Y_{e s}^{c}$ & Yes (five layers maximum) & Yes \\
\hline CoLM & Multilayer finite difference heat diffusion & $3.4 \mathrm{~m}$ & No & No & Yes (five layers maximum) & No \\
\hline ISBA & Multilayer Fourier solution & $12.0 \mathrm{~m}$ & No & Yes $^{c}$ & Yes (three layers maximum) & Yes \\
\hline JULES & Multilayer finite difference heat diffusion & $3.0 \mathrm{~m}$ & No & No & Yes (three layers maximum) & Yes \\
\hline LPJ-GUESS & Multilayer finite difference heat diffusion & $6-8 m$ & No & No & Yes (one layer) & No \\
\hline MIROC-ESM & Multilayer heat conduction & $14.0 \mathrm{~m}$ & No & No & Yes (three layers maximum) & No \\
\hline $\mathrm{ORCHa}$ and $\mathrm{ORCHb}$ & 1-D Fourier solution & $88.0 \mathrm{~m}$ & No & No & Yes (one layer) & Yes \\
\hline UVic & Multilayer finite difference heat diffusion & $250.0 \mathrm{~m}$ & No & Yes & Yes (one layer) & Yes \\
\hline UW-VIC & Multilayer finite difference heat diffusion & $25.0 \mathrm{~m}$ & No & Yes & Yes (two layers maximum) & Yes \\
\hline JSBACH & Modified Richtmayr-Morten implicit scheme & $10.0 \mathrm{~m}$ & No & Yes $^{c}$ & Yes (five layers maximum) & Yes \\
\hline TEM6 & Multilayer finite difference heat diffusion & $36.0 \mathrm{~m}$ & Yes & No & Yes (one layer) & No \\
\hline SiBCASA & Multilayer finite difference heat diffusion & $15.0 \mathrm{~m}$ & No & Yes & Yes (five layers maximum) & Yes \\
\hline GIPLa & Multilayer finite difference heat diffusion & $200.0 \mathrm{~m}$ & Yes & Yes & Yes (one layer) & Yes \\
\hline GIPLb & Multilayer finite difference heat diffusion & $200.0 \mathrm{~m}$ & Yes & Yes & Yes (one layer) & Yes \\
\hline
\end{tabular}

${ }_{b}^{a}$ Model implements algorithms for representing the effects of unfrozen water on phase change processes in frozen soil.

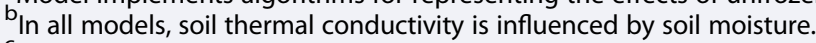

${ }^{\mathrm{c}}$ Organic horizon thickness is prescribed and is not prognostic.

[Decharme et al., 2011, 2013], (5) the Joint Scheme for Biosphere Atmosphere Coupling in Hamburg (JSBACH) land model [Ekici et al., 2014; Goll et al., 2015], (6) the Joint UK Land Environment Simulator (JULES) land model [Best et al., 2011; Clark et al., 2011], (7) the Lund-Potsdam-Jena General Ecosystem Simulator (LPJ-GUESS) dynamic vegetation model [Smith et al., 2001; Wania et al., 2009a, 2009b, 2010; Miller and Smith, 2012; Zhang et al., 2013], (8) the Model for Interdisciplinary Research on Climate Earth system model (MIROC-ESM) [Watanabe et al., 2011], (9) two versions of the Organizing Carbon and Hydrology in Dynamic Ecosystems-Institut Pierre-Simon Laplace (ORCHIDEE-IPSL) model (ORCHa and ORCHb) [Koven et al., 2009, 2011; Gouttevin et al., 2012a, 2012b], (10) the Simple Biosphere/Carnegie-Ames-Stanford Approach land model [Schaefer et al., 2011], (11) version 6 of the Terrestrial Ecosystems Model (TEM6) [Hayes et al., 2011, 2014], (12) the University of Victoria (UVic) Earth System Climate Model [Avis et al., 2011; MacDougall et al., 2012], and (13) the University of Washington Variable Infiltration Capacity (UW-VIC) model [Bohn et al., 2013a, 2013b; Chen et al., 2015]. The key features that influence soil thermal dynamics are compared in Table 1. The implementations of the GIPLa and GIPLb models in this study use the same nonlinear heat equations and the same parameterizations for soil thermal properties but differ in how snow insulation affects soil thermal dynamics. GIPLa uses empirical snow warming factors, whereas GIPLb increases the density of snow as it

Table 2. Comparison of Conceptual Representation of Soil Carbon Dynamics Among Models ${ }^{\mathrm{a}}$

\begin{tabular}{|c|c|c|c|c|c|c|c|c|c|}
\hline Model & General Depth & $\begin{array}{l}\text { Soil C Storage } \\
\text { Explicitly Treated } \\
\text { with Depth }\end{array}$ & $\begin{array}{c}\text { Moss } \\
\text { Horizon C } \\
\text { Considered }\end{array}$ & $\begin{array}{c}\text { Litter } \\
\text { Horizon C } \\
\text { Considered }\end{array}$ & $\begin{array}{l}\text { Organic } \\
\text { Horizon C } \\
\text { Considered }\end{array}$ & $\begin{array}{l}\mathrm{BIO} \mathrm{C}-\mathrm{CH}_{4} \\
\text { Losses } \\
\text { Considered }\end{array}$ & $\begin{array}{l}\text { Disturbance } \\
\text { Losses } \\
\text { Considered }\end{array}$ & $\begin{array}{c}\text { Lateral } \\
\text { Losses } \\
\text { Considered }\end{array}$ & $\begin{array}{l}\text { Time Step } \\
\text { of Flux } \\
\text { Estimates }\end{array}$ \\
\hline CLM4.5 & $4.0 \mathrm{~m}$ & Yes & No & Yes & Yes & Yes & Fire & Land use & $30 \mathrm{~min}$ \\
\hline CoLM & $3.4 \mathrm{~m}$ & No & No & Yes & No & No & Fire & No & $1 \mathrm{~h}$ \\
\hline ISBA & $1.0 \mathrm{~m}$ & No & No & Yes & No & No & No & No & $30 \mathrm{~min}$ to 1 day \\
\hline JULES & Unspecified & No & No & No & No & No & No & No & $30 \mathrm{~min}$ \\
\hline LPJ-GUESS & Unspecified & No & No & Yes & No & Yes & Fire & No & 1 month \\
\hline MIROC-ESM & Unspecified & No & No & No & No & No & $\mathrm{No}^{\mathrm{b}}$ & No & 1 day \\
\hline $\begin{array}{l}\mathrm{ORCHa} \\
\text { and ORCHb }\end{array}$ & $\begin{array}{l}2 \text { (ORCHa) or } \\
47 \mathrm{~m}(\mathrm{ORCHb})\end{array}$ & Yes & No & Yes & No & No & No & Land use & $30 \min$ to 1 day \\
\hline UVic & $3.35 \mathrm{~m}$ & Yes & No & No & Yes & No & No & Land use & $1 \mathrm{~h}$ \\
\hline UW-VIC & 1 to $3 \mathrm{~m}$ & No & No & Yes & No & Yes & No & No & $3 \mathrm{~h}$ \\
\hline JSBACH & Unspecified & No & No & Yes & No & No & No & No & $30 \mathrm{~min}$ \\
\hline TEM6 & Variable to $\sim 3 \mathrm{~m}$ & Yes & No & No & No & Yes & Yes & Yes (DOC export) & 1 month \\
\hline SiBCASA & $3.0 \mathrm{~m}$ & Yes & No & Yes & Yes & Yes & No & No & $30 \mathrm{~min}$ \\
\hline
\end{tabular}

${ }^{a}$ All models consider soil carbon losses from heterotrophic respiration.

${ }^{b}$ MIROC-ESM does consider fire and land use implicitly but does not report the associated fluxes. 
Table 3. Climate Data Sets Used to Drive Each Model

\begin{tabular}{|c|c|c|c|c|}
\hline Model & Climate Data Set & Short-Wave ${ }^{\mathrm{a}}$ Radiation Used & Long-Wave ${ }^{\mathrm{a}}$ Radiation Used & Vapor $^{\mathrm{a}}$ Pressure Used \\
\hline CLM4.5 & CRUNCEP4 $^{\mathrm{b}}$ & Yes & Yes $^{c}$ & Yes \\
\hline CoLM & Princeton $^{d}$ & Yes & Yes & Yes \\
\hline ISBA & WATCH $(1901-1978)^{\mathrm{e}}$ and WFDEI $(1978-2009)^{\mathrm{i}}$ & Yes & Yes & Yes \\
\hline JULES & WATCH $(1901-2001)^{\mathrm{e}}$ & Yes & Yes & Yes \\
\hline LPJ-GUESS & CRU TS $3.1^{\mathrm{f}}$ & $Y_{e s}{ }^{9}$ & No & No \\
\hline MIROC-ESM & CMIP5 drivers ${ }^{h}$ & Yes & Yes & Yes \\
\hline $\mathrm{ORCHa}$ and $\mathrm{ORCHb}$ & WATCH $(1901-1978)^{\mathrm{e}}$ and WFDEI (1978-2009) & Yes & Yes & Yes \\
\hline UVic & CRUNCEP4 ${ }^{\mathrm{b}}$ & Internally calculated & Internally calculated & Yes \\
\hline UW-VIC & $C R U^{j}$ and $U D e l^{k}$ & Internally calculated & Internally calculated & Yes \\
\hline JSBACH & WATCH (1901-1978) ${ }^{\mathrm{e}}$ [Beer et al., 2014, 1979-2009]' & Yes & Yes & Yes \\
\hline TEM6 & CRUNCEP4 ${ }^{\mathrm{b}}$ & Yes & No & No \\
\hline SiBCASA & CRUNCEP4 ${ }^{b}$ & Yes & Yes & Yes \\
\hline GIPLa & CRU TS $3.1^{f}$ & No & No & No \\
\hline GIPLb & CRU TS $3.1^{f}$ & No & No & No \\
\hline
\end{tabular}

${ }^{a}$ Entries in these columns indicate whether the simulation was driven by temporal variability in these variables.

biovy and Ciais [2011] (http://dods.extra.cea.fr/).

CLong-wave data set not from CRUNCEP4.

d Sheffield et al. [2006] (http://hydrology.princeton.edu/data.pgf.php).

e Weedon et al. [2011] (http://www.waterandclimatechange.eu/about/watch-forcing-data-20th-century).

Harris et al. [2014].

${ }^{9}$ Calculated from cloudiness data set.

$\mathrm{h}_{\text {Watanabe et al. [2011]. }}$

ihttp://www.eu-watch.org/gfx_content/documents/README-WFDEl.pdf.

${ }^{\mathrm{j}}$ Mitchell and Jones [2005] for temperature.

${ }^{k}$ Willmott and Matsuura [2001] for wind speed and precipitation with corrections [see Bohn et al., 2013a, 2013b].

Beer et al. [2014].

accumulates on the ground surface as described in Jafarov et al. [2013]. The key structural features that influence permafrost region $C$ dynamics are compared in Table 2. The time step of flux estimates ranges from a temporal resolution of 30 min to 1 month (Table 2). The two sets of simulations of the ORCHIDEE-IPSL model differ in the representation of the depth of soil $\mathrm{C}$, which is $2 \mathrm{~m}$ in ORCHa and up to $47 \mathrm{~m}$ in ORCHb.

\subsection{Simulation Protocol}

Driving data sets in this study were model dependent as a number of models were involved in activities that relied on the use of different retrospective forcing data sets. Therefore, each modeling group was free to choose appropriate driving data sets for climate, atmospheric $\mathrm{CO}_{2}, \mathrm{~N}$ deposition, disturbance, soil texture, and other forcing data. The driving data sets used by each model are documented in Table 3. Spin-up was also specific to each model, but it was conducted to support the delivery of simulation results starting in 1960.

To determine the relative effects of the atmospheric temperature, $\mathrm{CO}_{2}$, and precipitation drivers on the $\mathrm{C}$ cycle responses of the models, we conducted three additional simulations in addition to the simulation with all the drivers (the baseline simulation R01), in which we ran the models with detrended air temperature (the R02 simulation), constant $\mathrm{CO}_{2}$ (the R03 simulation), and detrended temperature and precipitation (the R04 simulations; see Table 4). Nine of the models that participated in this study provided results from R02, R03, and R04 simulations. The effect of changes in temperature and atmospheric $\mathrm{CO}_{2}$ between 1960 and 2009 were estimated by subtracting the results of the R02 and R03 simulations, respectively, from the R01 simulation. The effect of precipitation was estimated by subtracting the R04 from the R02 simulation.

Table 4. Simulations Conducted in This Study

Simulation ID

R01

R02

R03

R04
Simulation Name

Reference run

Constant temperature

Constant $\mathrm{CO}_{2}$

Constant temperature and precipitation
Simulation Description

Simulation for 1960 to 2009 with variability in all temporal drivers Simulation driven by detrended temperature for 1960 to 2009 with all other temporal driving data sets unaltered Simulation driven by constant $\mathrm{CO}_{2}$ for 1960 to 2009 (using 1960 level of $\mathrm{CO}_{2}$ ) with all other temporal driving data sets unaltered

Simulation driven by detrended temperature and detrended precipitation for the 1960 to 2009 with all other temporal driving data sets unaltered 
Table 5. Comparison of Mean, Standard Deviation, and Trend in Atmospheric $\mathrm{CO}_{2}$, Mean Annual Air Temperature, and Annual Precipitation Data Used to Drive the Models from 1960 to 2009 Across the Permafrost Region ${ }^{a_{* *}}$

\begin{tabular}{|c|c|c|c|c|c|c|c|c|c|c|}
\hline \multirow[t]{2}{*}{ Model } & \multirow{2}{*}{$\begin{array}{c}\text { Start and End of } \\
\text { Simulation with Transient } \\
\text { Climate Data }\end{array}$} & \multicolumn{3}{|c|}{$\begin{array}{c}\text { Atmospheric } \mathrm{CO}_{2} \text { Concentration } \\
(\mathrm{ppmv})\end{array}$} & \multicolumn{3}{|c|}{$\begin{array}{c}\text { Mean Annual Air Temperature } \\
\left({ }^{\circ} \mathrm{C}\right)\end{array}$} & \multicolumn{3}{|c|}{$\begin{array}{l}\text { Annual Precipitation } \\
\qquad(\mathrm{mm})\end{array}$} \\
\hline & & Mean & $\begin{array}{l}\text { Standard } \\
\text { deviation }\end{array}$ & $\begin{array}{c}\text { Trend }^{*} \\
\left(\mathrm{ppmv}_{\mathrm{yr}}{ }^{-1}\right)\end{array}$ & Mean & $\begin{array}{l}\text { Standard } \\
\text { deviation }\end{array}$ & $\begin{array}{l}\text { Trend } \\
\left({ }^{\circ} \mathrm{Cyr}^{-1}\right)\end{array}$ & Mean & $\begin{array}{l}\text { Standard } \\
\text { deviation }\end{array}$ & $\begin{array}{l}\text { Trend } \\
\left(\mathrm{mm} \mathrm{yr}^{-1}\right)\end{array}$ \\
\hline CLM4.5 & $1850-2005$ & 343.2 & 18.9 & $1.4^{*}$ & -7.19 & 0.62 & $0.03^{*}$ & 433.4 & 8.3 & $0.1 \mathrm{~ns}$ \\
\hline CoLM & $1950-2000$ & 339.4 & 16.3 & $1.4^{*}$ & -4.47 & 0.56 & $0.03^{*}$ & 542.2 & 15.1 & $0.0 \mathrm{~ns}$ \\
\hline ISBA & $1901-2009$ & 346.5 & 21.3 & $1.5^{*}$ & -5.70 & 0.65 & $0.03^{*}$ & 521.1 & 12.1 & $0.2 \mathrm{~ns}$ \\
\hline JULES & $1901-2000$ & 343.2 & 18.9 & $1.4^{*}$ & -6.22 & 0.63 & $0.03^{*}$ & 497.4 & 13.7 & $-0.1 \mathrm{~ns}$ \\
\hline LPJ-GUESS & $1901-2009$ & 345.5 & 25.2 & $1.7^{*}$ & -4.52 & 0.65 & $0.03^{*}$ & 453.5 & 9.2 & $0.2^{*}$ \\
\hline MIROC-ESM & $1850-2009$ & 345.8 & 21.3 & $1.5^{*}$ & -2.29 & 0.60 & $0.03^{*}$ & 685.7 & 18.0 & $0.8^{*}$ \\
\hline $\mathrm{ORCHa}$ & $1901-2009$ & 346.5 & 21.3 & $1.5^{*}$ & -6.94 & 0.84 & $0.05^{*}$ & 478.5 & 17.6 & $0.5^{*}$ \\
\hline $\mathrm{ORCHb}$ & $1901-2009$ & 350.0 & 21.3 & $1.5^{*}$ & -5.33 & 0.70 & $0.04^{*}$ & 430.1 & 13.0 & $0.3^{*}$ \\
\hline UVic & $1901-2009$ & 346.5 & 21.3 & $1.5^{*}$ & -4.52 & 0.66 & $0.03^{*}$ & 442.5 & 9.3 & $0.2^{*}$ \\
\hline UW-VIC & 1948-2006 & 343.7 & 19.3 & $1.4^{*}$ & -3.95 & 0.60 & $0.03^{*}$ & 589.9 & 37.7 & $-2.1^{*}$ \\
\hline JSBACH & $1901-2009$ & 346.5 & 21.3 & $1.5^{*}$ & -4.56 & 0.81 & $0.04^{*}$ & 521.9 & 20.1 & $-0.1 \mathrm{~ns}$ \\
\hline TEM6 & $1901-2009$ & 347.7 & 22.0 & $1.5^{*}$ & -3.83 & 0.62 & $0.03^{*}$ & 431.3 & 10.3 & $0.2^{*}$ \\
\hline SiBCASA & $1901-2009$ & 347.7 & 22.0 & $1.5^{*}$ & -3.83 & 0.62 & $0.03^{*}$ & 431.3 & 10.3 & $0.2^{*}$ \\
\hline GIPLa & $1901-2009$ & - & - & - & -4.52 & 0.65 & $0.03^{*}$ & 453.5 & 9.2 & $0.2^{*}$ \\
\hline GIPLb & $1901-2009$ & - & - & - & -4.52 & 0.65 & $0.03^{*}$ & 453.5 & 9.2 & $0.2^{*}$ \\
\hline
\end{tabular}

${ }^{\mathrm{a}}$ Mean, standard deviation, and trend were calculated from aggregated annual data for the entire region from 1960 to the end-of-simulation year.

*Significant trend at $\alpha=0.05$, ns $=$ nonsignificant trend at $\alpha=0.05$.

\section{Results}

\subsection{Comparison of Drivers}

Because of differences among the climate forcing data sets used to drive the models, the last year of the simulation varied among the models (Table 5). Among the atmospheric $\mathrm{CO}_{2}$ data set used to drive the models, the mean, standard deviation, and trend were similar (Table 5). In contrast, mean annual air temperature varied among the data sets used to drive the models by approximately $5^{\circ} \mathrm{C}$ from $-7.19^{\circ} \mathrm{C}(\mathrm{CLM} 4.5)$ to $-2.29^{\circ} \mathrm{C}$ (MIROC), reflecting, in part, the large uncertainty in the sparsely instrumented permafrost domain. However, the trend in mean annual air temperature was similar in all of the data sets used to drive the models $\left(0.03\right.$ to $\left.0.05^{\circ} \mathrm{Cyr}^{-1}\right)$. There was also substantial variation among the forcing data sets of annual precipitation, which varied from $433.4 \mathrm{~mm}$ (CLM4.5) to $685.7 \mathrm{~mm}$ (MIROC-ESM). The standard deviation in annual precipitation was less than $20.1 \mathrm{~mm}$ except in the case of the data set used to drive UW-VIC $(37.7 \mathrm{~mm})$. Ten of the models were run with forcing data sets that had significant trends in precipitation that ranged from $-2.1 \mathrm{~mm} \mathrm{yr}^{-1}$ (UW-VIC) to $0.8 \mathrm{~mm} \mathrm{yr}^{-1}$ (MIROC-ESM).

\subsection{Comparison of Permafrost Dynamics}

Across the simulation area, there was an approximately threefold range in the estimates of the area of permafrost, defined as the area over which maximum seasonal ALT was less than $3 \mathrm{~m}$ deep, ranging from 7.6 to $21.1 \times 10^{6} \mathrm{~km}^{2}$ among the models (Table 6). This range straddles the estimate of $16.2 \times 10^{6} \mathrm{~km}^{2}$ occupied by the continuous and discontinuous permafrost in the Northern Hemisphere [Slater and Lawrence, 2013]. The models all predict a loss of permafrost area (ALT $<3 \mathrm{~m}$ ) between 1960 and 2009 over the simulation area, but there are large differences in the magnitude of the predicted rates of loss among the models ( 0.2 to $58.8 \times 10^{3} \mathrm{~km}^{2} \mathrm{yr}^{-1}$; Figure $2 \mathrm{a}$ and Table 6). The amount of loss is not significantly related to the maximum soil depth (analysis of variance, $P=0.50, F=0.50$, d.f. $=14$ ). It is noteworthy that differences in the treatment of snow insulation between GIPLa and GIPLb led to a twofold difference in permafrost area and to a fourfold difference in the rate of permafrost area loss.

Among the models that ran the three sensitivity simulations, $84 \%$ of the change in permafrost area were explained by model sensitivities to changes in air temperature $\left(-22.11 \times 10^{3} \mathrm{~km}^{2} \mathrm{yr}^{-1}\right.$; Table 6 and Figure 2c). The mean effect of changes in precipitation is to increase permafrost area $\sim 800 \mathrm{~km}^{2} \mathrm{yr}^{-1}$, which is over an order of magnitude weaker than the temperature-induced changes (Table 6 and Figure 2d); the 
Table 6. Permafrost Area and $20 \mathrm{~cm}$ Soil Temperature Simulated by Process Models for 1960-2009

\begin{tabular}{|c|c|c|c|c|c|c|c|c|}
\hline \multirow{3}{*}{$\begin{array}{l}\text { Model } \\
\text { Units }\end{array}$} & \multirow{3}{*}{$\frac{\text { Permafrost Area }^{\mathrm{a}}}{10^{6} \mathrm{~km}^{2}}$} & \multicolumn{5}{|c|}{ Change in Permafrost Area ${ }^{b}$} & \multirow{3}{*}{$\frac{\text { Soil } T \text { at } 20 \mathrm{~cm}^{\mathrm{c}}}{{ }^{\circ} \mathrm{C}}$} & \multirow{3}{*}{$\frac{\text { Trend in } 20 \mathrm{~cm} \text { Soil } T^{\mathrm{b}}}{{ }^{\circ} \mathrm{C} \mathrm{yr}^{-1}}$} \\
\hline & & & & $10^{3} \mathrm{~km}^{2} \mathrm{yr}^{-1}$ & & & & \\
\hline & & Total & Temperature effect & Precipitation effect & $\mathrm{CO}_{2}$ effect & Interaction effect & & \\
\hline CLM4.5 & 15.77 & -22.77 & -23.25 & 1.04 & 0.92 & -1.48 & -2.28 & 0.02 \\
\hline CoLM & 7.62 & -0.20 & - & - & - & - & 1.69 & 0.00 \\
\hline ISBA & 20.86 & -38.52 & -46.80 & -0.73 & 0.53 & 8.48 & -5.26 & 0.02 \\
\hline JULES & 13.19 & -58.79 & -12.52 & 11.08 & 0.90 & -58.25 & 0.00 & 0.02 \\
\hline LPJ-GUESS & 17.41 & -34.96 & -48.65 & -0.30 & -1.03 & 15.02 & -2.20 & 0.02 \\
\hline MIROC-ESM & 13.02 & -5.34 & - & - & - & - & 0.13 & 0.02 \\
\hline $\mathrm{ORCHa}$ & 20.01 & -17.45 & -5.98 & 0.01 & -0.53 & -10.95 & -6.44 & 0.02 \\
\hline $\mathrm{ORCHb}$ & 16.32 & -15.25 & -10.40 & -7.22 & 0.11 & 2.26 & -1.56 & 0.02 \\
\hline UVic & 16.47 & -24.85 & -12.16 & -2.87 & 0.91 & -10.73 & -2.06 & 0.02 \\
\hline UW-VIC & 17.56 & -0.64 & -30.59 & 7.06 & 0.00 & 22.89 & -0.93 & 0.01 \\
\hline JSBACH & 20.39 & -38.57 & - & - & - & - & - & - \\
\hline TEM6 & 14.13 & -24.50 & -8.72 & -0.70 & 0.00 & -15.08 & -6.70 & 0.02 \\
\hline SiBCASA & 17.32 & -18.17 & - & - & - & - & -3.91 & 0.02 \\
\hline GIPLa & 11.60 & -5.76 & - & - & - & - & -3.79 & 0.02 \\
\hline GIPLb & 21.08 & -22.40 & - & - & - & - & -1.85 & 0.01 \\
\hline Model mean & 16.16 & -21.88 & $-22.11^{d}$ & $0.82^{d}$ & $0.20^{\mathrm{d}}$ & $-32.82^{d}$ & -2.51 & 0.02 \\
\hline
\end{tabular}

${ }^{a}$ Permafrost area defined as maximum seasonal active layer thickness $<3 \mathrm{~m}$ in 1960.

${ }^{b}$ Rate of change calculated between 1960 and end of the simulation specific to each model.

'Mean soil temperature at $20 \mathrm{~cm}$ in 1960.

dModel mean represents mean of nine models in column.

models differ substantially in their sensitivity to precipitation change. Locally, changes in snow depth and snow season length related to changes in precipitation or temperature can likely amplify or mitigate the soil temperature response to climate warming [Lawrence and Slater, 2010].

There is essentially no net sensitivity of simulated permafrost area to changes in atmospheric $\mathrm{CO}_{2}$ concentration among the models (approximately an increase of $200 \mathrm{~km}^{2} \mathrm{yr}^{-1}$; Table 6 and Figure 2b). However, there are strong interactions among the effects of temperature, precipitation, and atmospheric $\mathrm{CO}_{2}$ among the models (Table 6), with some models indicating substantial losses (JULES, ORCHa, UVic, and TEM6) and other substantial gains (ISBA, LPJ-GUESS, and UW-VIC) in permafrost area as a result of interactions. Only CLM4.5 and $\mathrm{ORCHb}$ indicate relatively minor interactions. The direction of interactions likely largely depends on

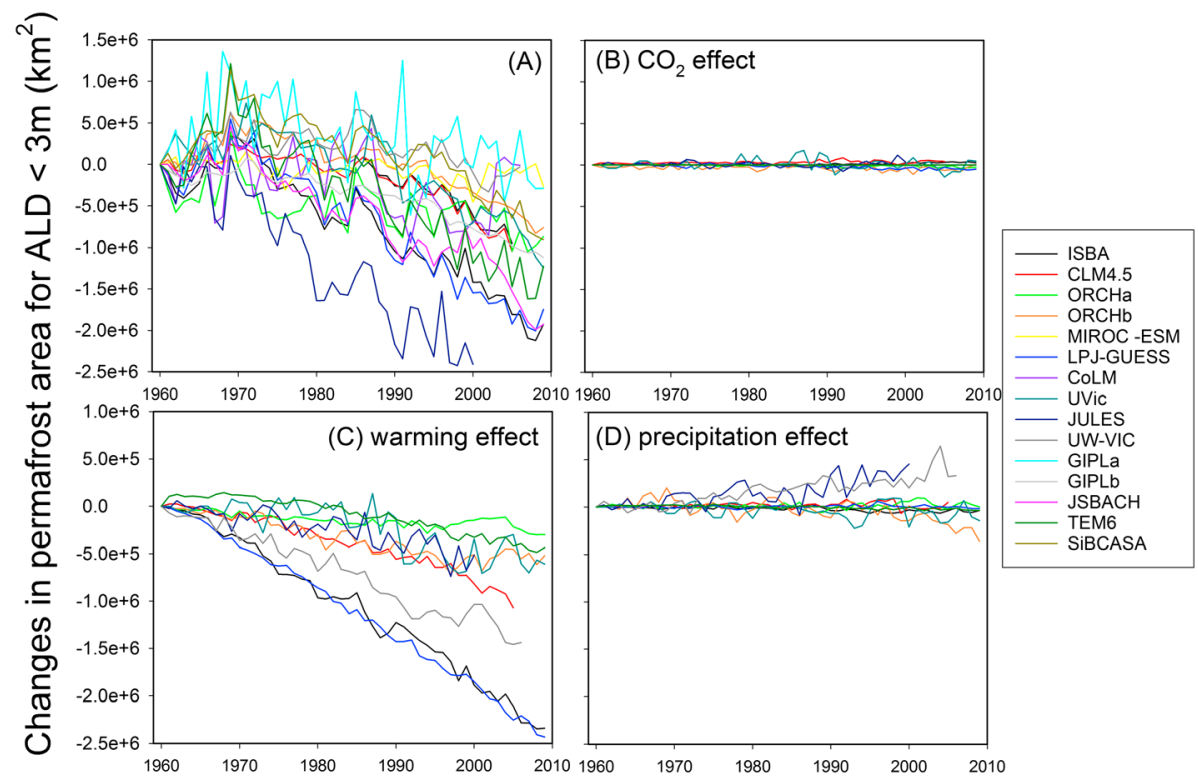

Figure 2. Simulated changes in (a) permafrost area from 1960 to 2009 and the sensitivity of simulated changes in permafrost area to changes in (b) atmospheric carbon dioxide, (c) temperature, and (d) precipitation from 1960 to 2009. 

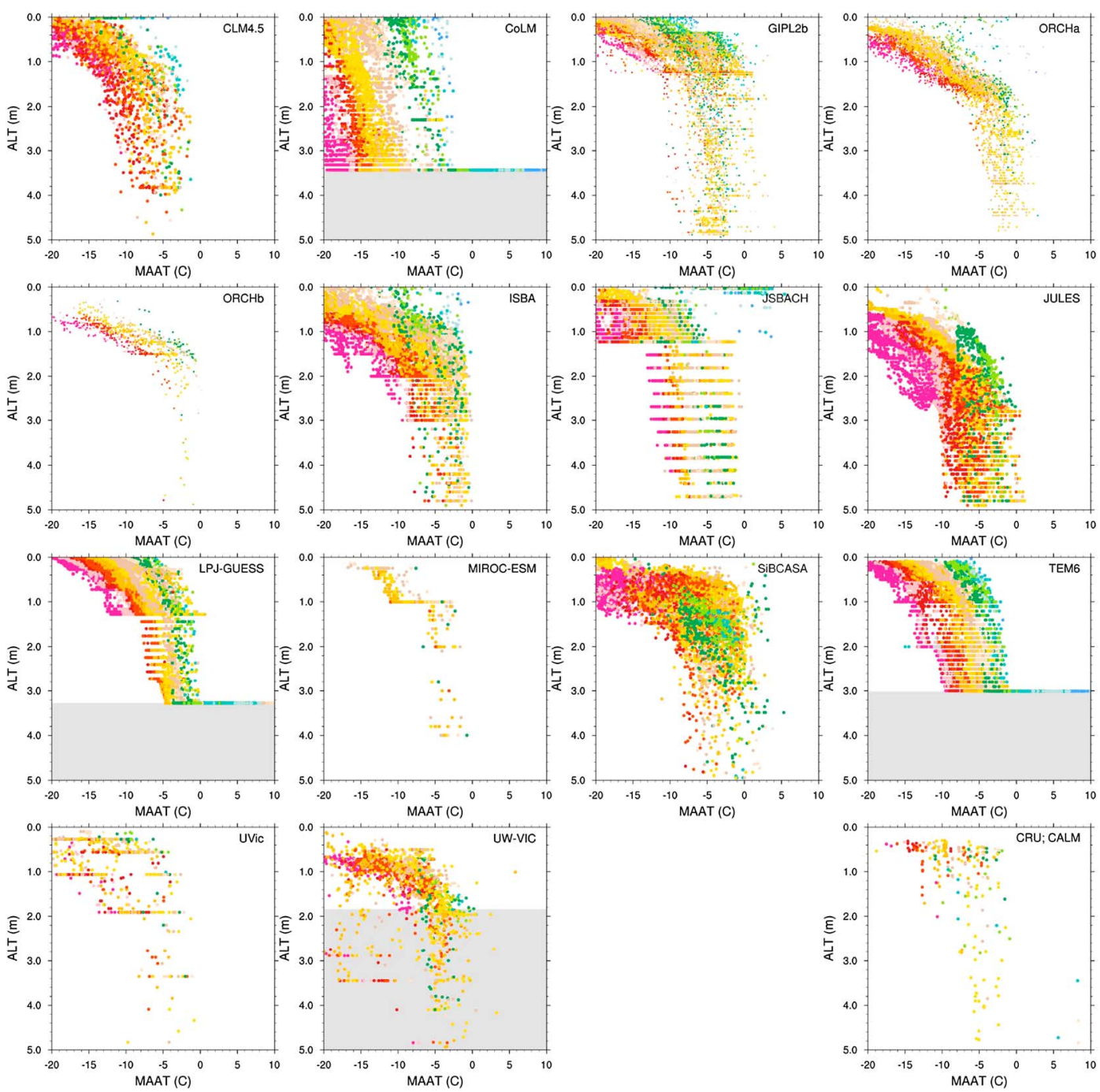

Amplitude of surface air seasonal cycle $\left({ }^{\circ} \mathrm{C}\right)$

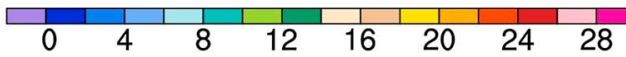

Figure 3. Model predictions of initial active layer thickness (ALT) plotted as functions of mean annual air temperature (MAAT) and the amplitude of the seasonal cycle in air temperature, following Koven et al. [2013b]. Also shown are observations of active layer thickness from the CALM data set against the grid cell climatology from the CRU database.

whether changes in snow depth increase or decrease insulation during winter, which would tend to enhance permafrost loss or counteract permafrost loss, respectively.

The models vary quite substantially in estimates of soil temperature at $20 \mathrm{~cm}$ in 1960 from -6.70 to $1.69^{\circ} \mathrm{C}$ (Table 6), and none of the structural differences among the models (Table 1) or differences in climate drivers (Table 5) explain the variation among the models. The trends in soil temperature at $20 \mathrm{~cm}$ vary from 0.00 to $+0.02^{\circ} \mathrm{Cyr}^{-1}$ among the models (Table 6), and the strength of these trends is not clearly related to structural differences (Table 1), climate drivers (Table 5), or to the rate of permafrost loss (Table 6).

In addition to large variations in initial permafrost extent and soil temperatures, model predictions of active layer thickness vary substantially. Figure 3 shows the initial model predictions of ALT as functions of climate, following Koven et al. [2013b], as compared to observations of the same using mean active layer thickness from the Circumpolar Active Layer Monitoring network [Brown et al., 2000] as compared to climatological temperatures from the CRU database [Mitchell and Jones, 2005]. While most models tend to show an overall pattern of climate controls on ALT that is similar and consistent with observations, key differences can be 
Table 7. Carbon Storage in 1960 and Changes in Carbon Storage ${ }^{a}$ for 1960-2009 Simulated by Process-Based Models

\begin{tabular}{|c|c|c|c|c|c|c|}
\hline Model & Soil $C^{b}$ & Del Soil C & $\operatorname{Veg} C^{c}$ & Del Veg C & $E \cos C^{d}$ & Del Eco C \\
\hline Units & $10^{3} \mathrm{gCm}^{-2}$ & $\mathrm{gCm}^{-2} \mathrm{yr}^{-1}$ & $10^{3} \mathrm{gCm}^{-2}$ & $\mathrm{gCm}^{-2} \mathrm{yr}^{-1}$ & $10^{3} \mathrm{gCm}^{-2}$ & $\mathrm{gCm}^{-2} \mathrm{yr}^{-1}$ \\
\hline CLM4.5 & 41.4 & 1.4 & 3.3 & 3.3 & 44.6 & 5.1 \\
\hline CoLM & 9.9 & 2.8 & 5.6 & 3.0 & 15.5 & 6.5 \\
\hline ISBA & 26.8 & 20.6 & 4.1 & 10.3 & 30.9 & 30.9 \\
\hline JULES & 13.3 & 10.8 & 3.1 & 5.6 & 16.5 & 16.4 \\
\hline LPJ-GUESS & 16.8 & 3.1 & 2.5 & 5.3 & 19.3 & 8.3 \\
\hline MIROC-ESM & 38.7 & 14.7 & 2.7 & 2.9 & 41.4 & 17.7 \\
\hline $\mathrm{ORCHa}$ & 16.0 & 4.9 & 0.5 & 0.8 & 16.6 & 5.7 \\
\hline $\mathrm{ORCHb}$ & 31.3 & 13.5 & 6.2 & 17.0 & 37.5 & 30.5 \\
\hline UVic & 42.2 & 6.6 & 1.2 & 1.6 & 43.4 & 8.2 \\
\hline UW-VIC & 73.4 & 20.6 & - & - & 73.4 & 20.6 \\
\hline JSBACH & 30.0 & 6.1 & 1.9 & 4.5 & 31.9 & 10.7 \\
\hline TEM6 & 35.3 & 3.5 & 4.1 & 5.3 & 39.4 & 8.8 \\
\hline SiBCASA & 27.3 & 2.4 & 3.9 & 7.9 & 31.2 & 10.3 \\
\hline Model mean ${ }^{\mathrm{e}}$ & 31.0 & 8.5 & 3.3 & 5.6 & 34.0 & 13.8 \\
\hline Units $^{f}$ & $\mathrm{PgC}$ & $\operatorname{TgCyr}^{-1}$ & $\mathrm{PgC}$ & $\mathrm{TgCyr}^{-1}$ & $\mathrm{PgC}$ & $\operatorname{TgCyr}^{-1}$ \\
\hline CLM4.5 & 1278 & 41.8 & 101 & 103.0 & 1379 & 156.1 \\
\hline CoLM & 306 & 86.3 & 172 & 91.3 & 478 & 199.3 \\
\hline ISBA & 828 & 637.6 & 126 & 316.7 & 954 & 954.3 \\
\hline JULES & 412 & 333.5 & 97 & 173.0 & 509 & 506.5 \\
\hline LPJ-GUESS & 518 & 94.3 & 77 & 163.2 & 595 & 257.5 \\
\hline MIROC-ESM & 1196 & 455.3 & 83 & 89.9 & 1279 & 545.3 \\
\hline $\mathrm{ORCHa}$ & 495 & 151.8 & 17 & 23.6 & 512 & 175.4 \\
\hline $\mathrm{ORCHb}$ & 966 & 416.6 & 192 & 526.1 & 1158 & 942.7 \\
\hline UVic & 1303 & 202.6 & 37 & 49.5 & 1340 & 252.1 \\
\hline UW-VIC & 2268 & 637.0 & - & - & 2268 & 637.0 \\
\hline JSBACH & 925 & 188.7 & 59 & 140.3 & 985 & 329.0 \\
\hline TEM6 & 1090 & 108.4 & 126 & 162.9 & 1216 & 271.3 \\
\hline SiBCASA & 843 & 73.2 & 119 & 243.4 & 963 & 316.6 \\
\hline Model Mean $^{\mathrm{e}}$ & 956 & 263.6 & 100 & 167.2 & 1049 & 426.4 \\
\hline
\end{tabular}

${ }^{a}$ Rate of change calculated over the period 1960 through end of the simulation specific to each model.

${ }^{b}$ Soil C is the estimate at the beginning of 1960 and includes litter C, organic horizon C, mineral soil C, coarse woody debris, land use $C$ pools, and soil $C$ exudates.

${ }^{\mathrm{C}} \mathrm{Veg} C$ is the estimate at the beginning of 1960 and includes leaves, stem, and root $\mathrm{C}$.

$d_{E C O} C$ is the sum of soil $C$ and veg $C$.

e Model mean calculated based only on those models contributing estimates.

$\mathrm{f} \mathrm{Pg}=10^{15} \mathrm{~g}$ and $\mathrm{Tg}=10^{12} \mathrm{~g}$.

seen in the minimum ALT, the maximum mean annual air temperature at which permafrost occurs, and the slope and shape of the ALT-air temperature relationship. Further diagnostics (Figures S1-S6 in the supporting information) applying the analysis of Koven et al. [2013b] to this set of models, and as compared to soil temperature data from the IPY-TSP database [Romanovsky et al., 2010], identify patterns that explain some of these differences, including the numerical implementation of freeze/thaw processes and the snow and soil thermal processes that govern heat exchange between permafrost and the atmosphere. However, these patterns are complex and no single variable explains the bulk of model differences in ALT thermal sensitivity to climate variability. As a whole, the set of models here show smaller biases in these comparisons with ALT than the Coupled Model Intercomparison Project phase 5 (CMIP5) models [Koven et al., 2013b].

\subsection{Comparison of Carbon Dynamics}

\subsubsection{Simulated Carbon Budget From 1960 to 2009}

Across the 13 simulations that included $C$ dynamics, there is a 7 -fold difference in the estimates of soil $C$ (306 to $2268 \mathrm{Pg} \mathrm{C}$ ), an 11 -fold difference in vegetation C (17 to $192 \mathrm{Pg} \mathrm{C}$ ), and a 5 -fold difference in ecosystem C ( 478 to $2268 \mathrm{Pg}$ C) simulated in 1960 for the permafrost region (Table 7). Among the 13 simulations, the mean changes in vegetation $C$ are 167 (24-526) $\mathrm{Tg} \mathrm{Cyr}^{-1}$ and in soil $\mathrm{C}$ are 264 (42-637) $\mathrm{Tg} \mathrm{Cyr}^{-1}$ across the permafrost region between 1960 and 2009 (Figure 4 and Table 7). All of the models simulated increases in both vegetation and soil $C$ storage, although there is more than an order of magnitude difference among the models in the estimated rate of increase (Figure 4 and Table 7). Among the models, variation in the rate of vegetation and soil $\mathrm{C}$ increase is not related to variation in the starting year of simulation (Table 5). 


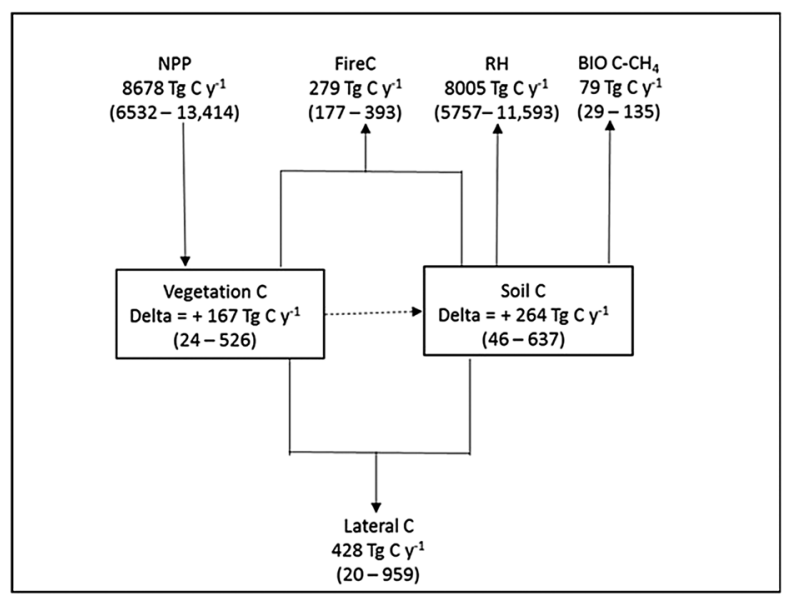

Figure 4. The carbon budget for the permafrost region across simulations by nine models. Note that the mean fluxes do not add up to the mean change in pools because not all models simulate fire $\mathrm{C}, \mathrm{BIO}$ $\mathrm{C}-\mathrm{CH}_{4}$, and lateral $\mathrm{C}$ fluxes.
Except for two of the models, the range of NEE (RH + fire C - NPP) simulated among the models between 1960 and 2009 (Table 8) falls within the 0 to $-800 \mathrm{TgCyr}^{-1}$ range of uncertainty among atmospheric inversion estimates for the net exchange of $\mathrm{CO}_{2}$ by the permafrost region with the atmosphere in the late twentieth century [McGuire et al., 2009; Hayes et al., 2011]. Mean NPP is approximately $700 \mathrm{TgCyr}^{-1}$ greater than $\mathrm{RH}$ (Table 8), and this difference explains most of the increases in $\mathrm{C}$ storage. Mean losses from fire emissions (279 $\mathrm{TgCyr}^{-1}$ in five models), $\mathrm{BIO} \mathrm{C}-\mathrm{CH}_{4}$ (79 $\mathrm{Tg} \mathrm{Cyr}^{-1}$ in four models), and lateral transfers ( $321 \mathrm{Tg} \mathrm{Cyr}^{-1}$ in five models) are approximately equal to the mean difference between NPP and RH among all the models but do not factor as strongly into

Table 8. Carbon Fluxes ${ }^{\mathrm{a}}$ Simulated by Process Models for 1960-2009

\begin{tabular}{|c|c|c|c|c|c|c|c|c|}
\hline Model & NPP & $\mathrm{RH}$ & NEP & Fire C & $\mathrm{NEE}^{\mathrm{c}}$ & $\mathrm{BIO} \mathrm{C}-\mathrm{CH}_{4}$ & Lateral C & $\mathrm{NECB}^{\mathrm{d}}$ \\
\hline Units & $\begin{array}{l}\mathrm{gCm}_{2} \mathrm{yr}^{-1} \\
-\end{array}$ & $\begin{array}{l}\mathrm{gCm}_{2} \mathrm{yr}^{-1} \\
\mathrm{yr}^{-}\end{array}$ & $\underset{2}{\mathrm{gCm}_{\mathrm{yr}^{-1}}}$ & $\underset{2}{\mathrm{gCm}_{\mathrm{yr}^{-1}}}$ & $\underset{2}{\mathrm{gCm}_{\mathrm{yr}^{-1}}}$ & $\underset{2}{\mathrm{gCm}^{-1} \mathrm{mr}^{-1}}$ & $\begin{array}{l}\mathrm{gCm}_{2} \mathrm{yr}^{-1} \\
.\end{array}$ & $\underset{2}{\mathrm{gCm}_{\mathrm{yr}^{-1}}}$ \\
\hline CLM4.5 & 281.7 & 258.5 & 23.1 & 9.9 & -13.3 & 2.4 & 5.7 & 5.2 \\
\hline CoLM & 253.8 & 240.0 & 13.7 & 5.7 & -8.0 & - & - & 8.0 \\
\hline ISBA & 354.3 & 323.3 & 31.0 & - & -31.0 & - & - & 31.0 \\
\hline JULES & 316.6 & 300.2 & 16.4 & - & -16.4 & - & - & 16.4 \\
\hline LPJ-GUESS & 212.0 & 186.4 & 25.6 & 12.7 & -12.9 & 4.4 & - & 8.5 \\
\hline MIROC-ESM & 324.3 & 306.6 & 17.7 & - & -17.7 & - & - & 17.7 \\
\hline $\mathrm{ORCHa}$ & 220.1 & 198.9 & 21.2 & - & -21.2 & - & 15.5 & 5.7 \\
\hline $\mathrm{ORCHb}$ & 434.3 & 375.4 & 59.0 & 5.9 & -53.0 & - & 28.3 & 24.7 \\
\hline UVic & 241.7 & 235.0 & 6.7 & - & -6.7 & - & 0.7 & 6.1 \\
\hline UW-VIC & 264.7 & 243.3 & 21.4 & - & -21.4 & 2.5 & - & 18.9 \\
\hline JSBACH & 287.8 & 276.1 & 11.7 & - & -11.7 & - & - & 11.7 \\
\hline TEM6 & 211.5 & 190.0 & 21.5 & 10.9 & -10.7 & 0.9 & 1.9 & 7.9 \\
\hline SiBCASA & 250.3 & 236.0 & 14.4 & - & -14.4 & - & - & 14.4 \\
\hline Model Mean ${ }^{\mathrm{e}}$ & 281.0 & 259.2 & 21.8 & 9.0 & -18.3 & 2.5 & 10.4 & 13.5 \\
\hline Units $^{f}$ & $\mathrm{PgCyr}^{-1}$ & $\mathrm{PgCyr}^{-1}$ & $\operatorname{TgCyr}^{-1}$ & $\operatorname{TgCyr}^{-1}$ & $\operatorname{TgCyr}^{-1}$ & $\operatorname{Tg} C \mathrm{yr}^{-1}$ & $\operatorname{TgCyr}^{-1}$ & $\operatorname{Tg} \mathrm{yr}^{-1}$ \\
\hline CLM4.5 & 8.7 & 8.0 & 715 & 305 & -410 & 75 & 175 & 161 \\
\hline CoLM & 7.8 & 7.4 & 424 & 177 & -247 & - & - & 247 \\
\hline ISBA & 10.9 & 10.0 & 959 & - & -959 & - & - & 959 \\
\hline JULES & 9.8 & 9.3 & 506 & - & -506 & - & - & 506 \\
\hline LPJ-GUESS & 6.5 & 5.8 & 790 & 393 & -397 & 135 & - & 262 \\
\hline MIROC-ESM & 10.0 & 9.5 & 545 & - & -545 & - & - & 545 \\
\hline $\mathrm{ORCHa}$ & 6.8 & 6.1 & 655 & - & -655 & - & 479 & 177 \\
\hline $\mathrm{ORCHb}$ & 13.4 & 11.6 & 1821 & 184 & -1637 & - & 875 & 762 \\
\hline UVic & 7.5 & 7.3 & 207 & - & -207 & - & 20 & 187 \\
\hline UW-VIC & 8.2 & 7.5 & 661 & - & -661 & 76 & - & 585 \\
\hline JSBACH & 8.9 & 8.5 & 360 & - & -360 & - & - & 360 \\
\hline TEM6 & 6.5 & 5.9 & 665 & 335 & -330 & 29 & 59 & 243 \\
\hline SiBCASA & 7.7 & 7.3 & 444 & - & -444 & - & - & 444 \\
\hline Model Mean ${ }^{\mathrm{e}}$ & 8.7 & 8.0 & 673 & 279 & -566 & 79 & 321 & 418 \\
\hline
\end{tabular}




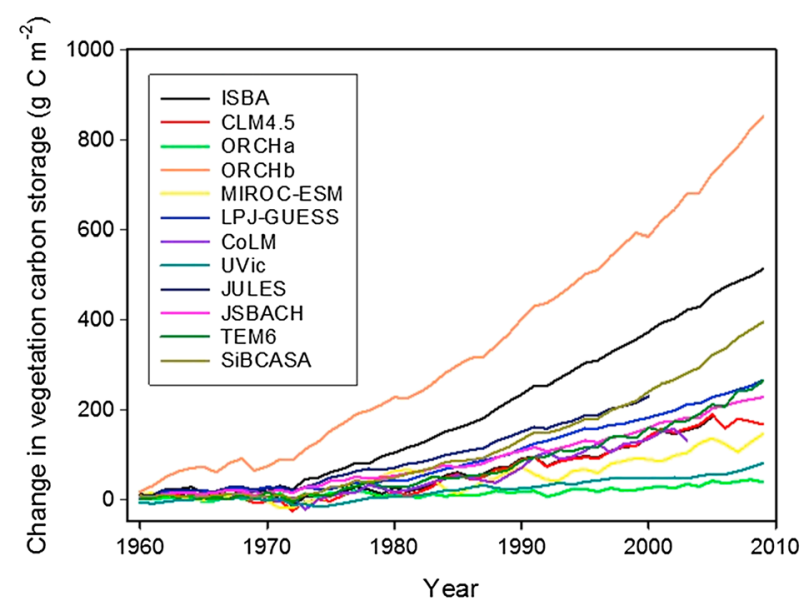

Figure 5. Simulated changes in vegetation carbon storage between 1960 and 2009 among the models.

In general, the models indicate that changes in vegetation $C$ storage across the permafrost region started to increase in the $1970 \mathrm{~s}$ and continued to increase through 2009 (Figure 5). Seven of the simulations indicate cumulative increases in vegetation C of less than $200 \mathrm{~g} \mathrm{C} \mathrm{m}^{-2}$ across the time period. Among the models that conducted simulations to partition the effects of $\mathrm{CO}_{2}$, temperature, and precipitation, 55\% of increases in vegetation $\mathrm{C}$ storage were explained by the model sensitivities to increases in atmospheric $\mathrm{CO}_{2}$ with the remainder driven by temperature changes, consistent with previous studies [Schaefer et al., 2002] (Figure 6a). The models vary in their sensitivity to increasing air temperature with five models (ORCHa, ORCHb, TEM6, ISBA, and LPJ-GUESS) indicating that warming tended to increase vegetation $C$ and two models (CLM4.5 and UVic) indicating that warming tended to slightly decrease vegetation C (Figure 6b). Further analyses showed that the reasons for decreased vegetation were different between CLM4.5 (increase in fire activity with warming) and UVic (increase in autotrophic respiration of needleleaf trees with warming). The mean responses to changing temperature only explained $16 \%$ of the mean response in vegetation $C$. Mean responses to changes in precipitation explained only $1 \%$ of the mean response in vegetation $\mathrm{C}$ (Figure $6 \mathrm{c}$ ). Interestingly, the mean of interactions among responses to $\mathrm{CO}_{2}$, temperature, and precipitation explained $28 \%$ of the mean response in vegetation $C$.

While all of the simulations indicate that soil C storage increases between 1960 and 2009, there was substantial variation among the simulations (Figures 4 and 7 and Table 7). The responses of the models that consider soil $C$ with depth indicate marginally significantly less additional soil $C$ storage than those of the models that do not consider soil $C$ with depth (one-tailed two-sample $t$ test, $t=1.52, P=0.08$, d.f. $=11$ ). The analysis of the sensitivity of soil $\mathrm{C}$ storage to changes in environmental drivers indicates that atmospheric $\mathrm{CO}_{2}$ (Figure 8a) contributes $+60 \%$ of the overall mean response, air temperature (Figure $8 b$ ) $-33 \%$, precipitation (Figure $8 c$ ) $+1 \%$, and interactions $+74 \%$. The importance of interactions in the response of soil $\mathrm{C}$ is because there are several different patterns responsible for overall responses with respect to mixtures of strong or weak positive sensitivities to $\mathrm{CO}_{2}$ and strong or weak positive or negative sensitivities to temperature and precipitation (Figure 8). Only one of the model simulations resulted in a positive sensitivity of soil $\mathrm{C}$ to warming. We found no difference in the temperature sensitivity of soil $C$ storage among the models that explicitly represent soil $C$ with depth and the remaining models (two-sample $t$ test: $t=0.61, P=0.28$, d.f. $=7$ ). The large variability in sensitivity to different drivers may mask the relative importance of representing soil $\mathrm{C}$ with depth. For example, the lower temperature sensitivity of ORCHb $\left(-18 \mathrm{~g} \mathrm{Cm}^{-2}\right)$ in comparison to that of ORCHa $\left(168 \mathrm{~g} \mathrm{Cm}^{-2}\right.$; Figure $8 \mathrm{~b}$ ) is putatively caused by the deeper depth of soil $\mathrm{C}$ simulated by ORCHb.

Among the models, the simulated changes in both vegetation and soil $C$ are significantly correlated with the simulated trend in NPP between 1960 and 2009 (vegetation $C: R=0.64, P=0.024, N=12$; soil $\mathrm{C}: R=0.70, P=0.007, N=13)$. The response of the trend in simulated NPP is dominated by the trend in simulated gross primary production (GPP) rather than by changes in simulated $C$ use efficiency (NPP/GPP) among the models (analysis not shown). In comparison with the trend of the GPP estimates in the Jung et al. [2011] data product for the permafrost region between 1982 and $2009\left(0.39 \mathrm{~g} \mathrm{C} \mathrm{m}^{-2} \mathrm{yr}^{-1}\right)$, the trend in the GPP estimates among the models is significantly larger (mean: $2.08 \pm 0.17 \mathrm{~g} \mathrm{Cm}^{-2} \mathrm{yr}^{-1}$; range: 1.24 to 

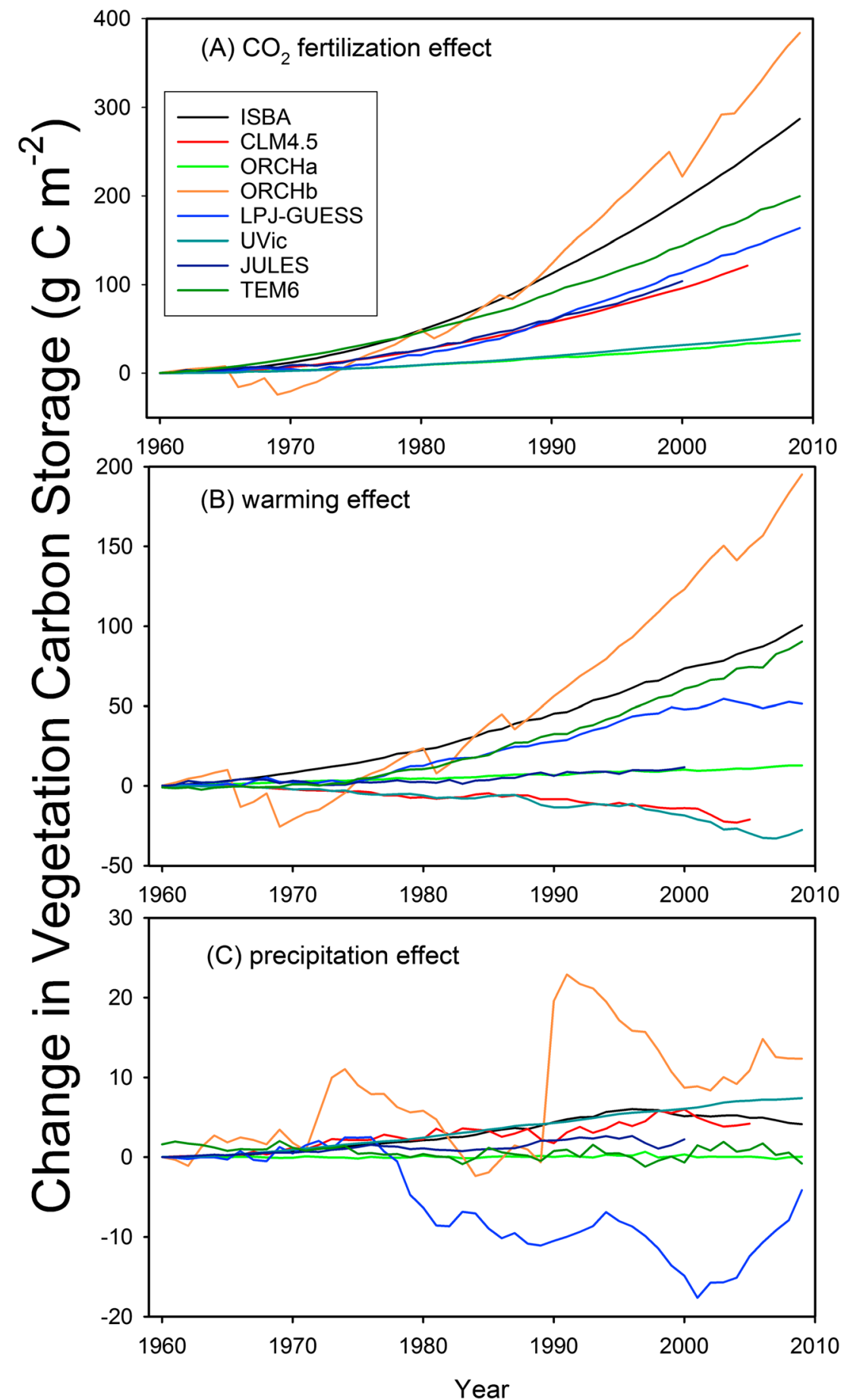

Figure 6. The sensitivity of simulated changes in vegetation carbon storage to changes in (a) atmospheric $\mathrm{CO}_{2}$, (b) air temperature, and (c) precipitation. Note the different $y$ axis scales.

$3.59 \mathrm{~g} \mathrm{C} \mathrm{m}^{-2} \mathrm{yr}^{-1}$; Figure 9; one-sample $t$ test: $\left.t=12.31, N=14, P<10^{-8}\right)$. Among the models that ran the sensitivity analyses, there are large differences in the sensitivity of GPP to changes in air temperature, atmospheric $\mathrm{CO}_{2}$, and precipitation. Changes in temperature and precipitation contribute approximately $50 \%$ each to the trend in GPP for four of the models (LPJ-GUESS, ORCHa, TEM6, and UW-VIC; analysis not shown). In contrast, the increase in GPP simulated by JULES mainly results from $\mathrm{CO}_{2}$ sensitivity $(\sim 80 \%)$, whereas that simulated by UVic has a large contribution of changes in both $\mathrm{CO}_{2}$ and precipitation ( 40\% each). 


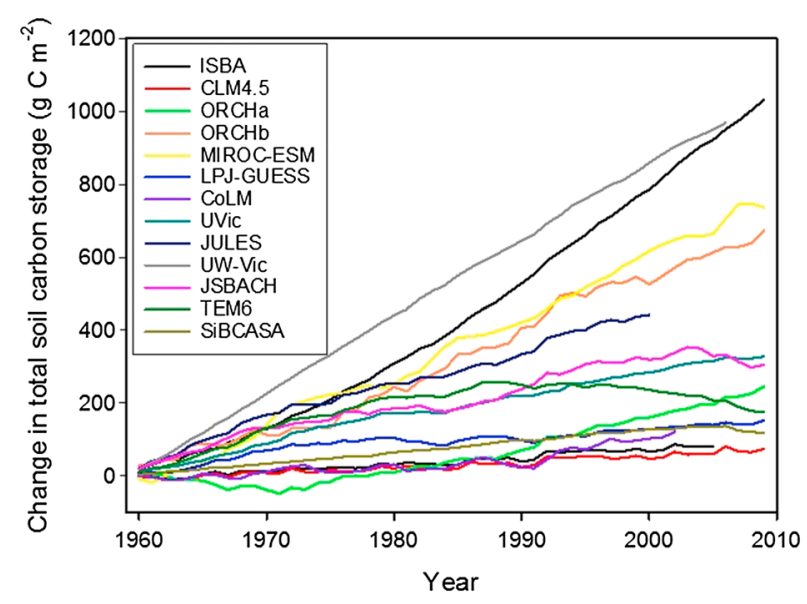

Figure 7. Simulated changes in soil carbon storage between 1960 and 2009 among the models.

\section{Discussion}

A large loss of $C$ from the permafrost region in response to climate change has the potential to compromise mitigation efforts aimed at slowing the pace of climate change [McGuire et al., 2009, 2010b]. Therefore, it is important to assess the degree to which the climate system is sensitive to the loss of $C$ in the permafrost region. However, most Earth system models cannot yet adequately represent permafrost [Koven et al., 2013b; Slater and Lawrence, 2013] or permafrost $C$ dynamics to assess the permafrost $C$ response to projected climate change. A recent synthesis has estimated the range of potential loss of $C$ from soils in the permafrost region to be between 65 and $240 \mathrm{Pg} \mathrm{C}$ by 2100 [Schuur et al., 2015], but these estimates do not account for the responses of plant production and vegetation $C$ and inputs of new plant production into soil $C$ pools that might offset losses of $C$ from soils. Process-based models are tools that are capable of simultaneously considering both plant production and soil $\mathrm{C}$ responses to climate change. Recent process-based model analyses that consider the exposure of permafrost $C$ from the thawing of permafrost indicate that permafrost region could lose between 28 and $174 \mathrm{PgC}$ by 2100 and between 345 and $529 \mathrm{Pg} C$ by 2300 under business as usual climate warming trajectories (Representative Concentration Pathway 8.5 [Schuur et al., 2015; Koven et al., 2011, 2015; Schaefer et al., 2011, 2014; Schneider von Deimling et al., 2012; MacDougall et al., 2012; Burke et al., 2012, 2013; Schaphoff et al., 2013; Zhuang et al., 2006]). These ranges translate into a range of 0.13 to $0.27^{\circ} \mathrm{C}$ additional global warming by 2100 and up to $0.42^{\circ} \mathrm{C}$ by 2300 [Schaefer et al., 2012a, 2014].

In this study, we find that models agree that between 1960 and $2009 \mathrm{C}$ has been accumulating in permafrost ecosystems (both in vegetation and soil C stocks), even though there has been modest permafrost thaw and active layer deepening. For models that couple the active layer deepening with soil $\mathrm{C}$ dynamics, this means that the inputs of new $C$ into the soils are greater than the loss of newly exposed permafrost soil $C$. The result that $C$ is accumulating in the permafrost region is not unexpected, as prior observation- and model-based studies have indicated that the permafrost region has been a $C$ sink over the last 60 years [McGuire et al., 2009; Qian et al., 2010]. What was not necessarily expected is that this broad set of land models that have experienced targeted permafrost and permafrost- $C$ dynamic development would exhibit such large differences in the mean and trends of ecosystem $C$ stocks, as well as responses of these stocks to climate change and $\mathrm{CO}_{2}$ fertilization since 1960. The large differences in the representation in these models of historical permafrost- $C$ dynamics suggest that future projections will also likely show substantial uncertainty.

A step toward reducing such uncertainty in the range of additional warming estimated by process-based models is to better understand the sources of uncertainty among models [Luo et al., 2016]. Because there has already been substantial warming in the permafrost region over the last half century, a retrospective analysis over this time period has the potential to better understand the sensitivity of $C$ simulated by processbased models in the permafrost region. In this study, we analyzed the simulated dynamics of permafrost and soil $C$ in the permafrost region since 1960 by process-based models to understand what factors explain variability in the sensitivity of permafrost and permafrost $C$ pools among the models.

The sensitivity of permafrost and ecosystem $C$ pools in the permafrost region depends in part on the exposure to changes in atmospheric $\mathrm{CO}_{2}$ and climate. Because changes in atmospheric $\mathrm{CO}_{2}$ and temperature from 1960 to 2009 did not vary substantially among the forcing data sets used to drive models, the responses of the simulated changes in $\mathrm{C}$ largely reflect differences in the models. In contrast, changes in precipitation did vary substantially among data sets used to force the models. However, the magnitude of the variability in the sensitivity of the models to changes in precipitation was much less than that of the models to changes in atmospheric $\mathrm{CO}_{2}$ and temperature. Thus, we feel that our analysis of the variability in the sensitivity of 

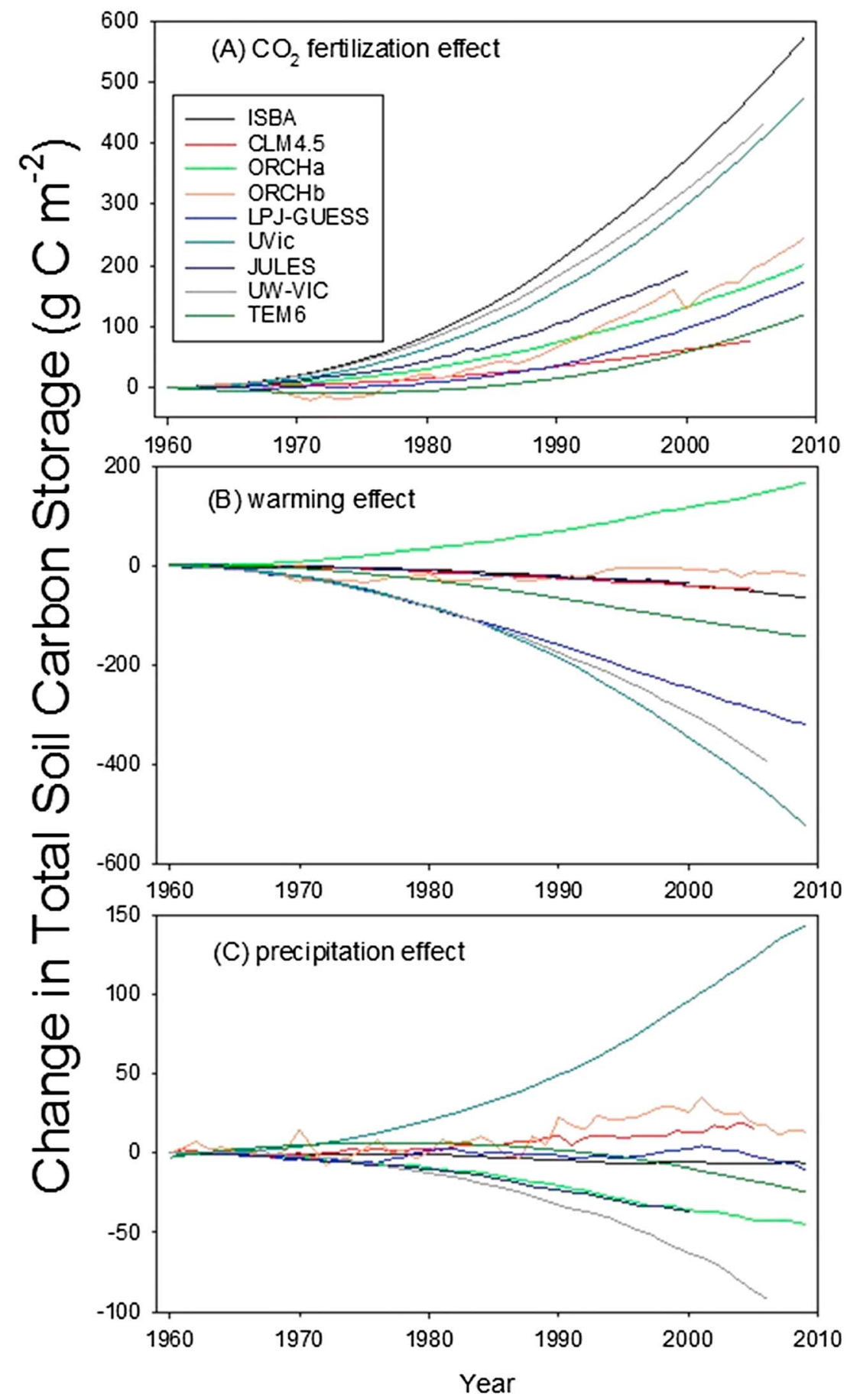

Figure 8. The sensitivity of simulated changes in soil carbon storage to changes in (a) atmospheric $\mathrm{CO}_{2}$, (b) air temperature, and (c) precipitation.

permafrost and C dynamics between 1960 and 2009 largely reflects differences among models in their sensitivity to drivers as opposed to differences in the forcing data sets used to drive the models.

\subsection{Means and Trends in Simulated Permafrost Area From 1960 to 2009}

The models compared in this study exhibit a wide range of simulated permafrost area in 1960 (7.0$21.210^{6} \times \mathrm{km}^{2}$ ), with 9 of the 15 simulations falling within $20 \%$ of the observed estimate of $16.2 \times 10^{6} \times \mathrm{km}^{2}$ for near-surface permafrost area [see Slater and Lawrence, 2013]. Nonetheless, the wide 


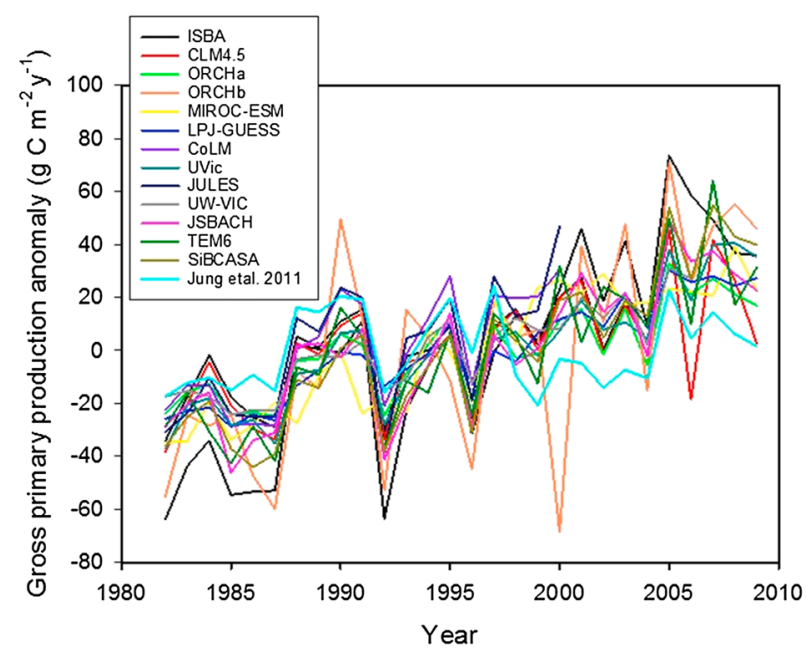

Figure 9. Comparison of changes in gross primary production for the permafrost region from 1982 to 2009 between the model simulations in this study and the data product of Jung et al. [2011]. range of simulated permafrost area in this study is somewhat surprising. The considerable differences in forcing temperature and precipitation do not directly correlate with the variations in simulated 1960 permafrost area, which points to structural and parameterization differences as the likely source of the strong differences among models. For example, there is a twofold difference in permafrost area between GIPLa and GIPLb because of differences in the way that snow affects soil thermal dynamics. Koven et al. [2013b] report that permafrost area in the coupled CMIP5 climate models varies even more $\left(2.8-28.6 \times 10^{6} \mathrm{~km}^{2}\right.$ for 1850), which can be attributed partly to biases in the simulated permafrost-domain climates of these models and partly to more severe deficiencies such as the general lack of soil organic horizons in the land models included in the CMIP5 comparison [Slater and Lawrence, 2013] compared to the models that have been more specifically targeted for permafrost processes considered in this study. Thus, it is clearly important to reduce uncertainties in precipitation, which are substantial in this study, as well as to reduce uncertainties in how models represent both snow and organic horizon insulation, for making progress in reducing the range of simulated initial permafrost area among models.

There is also a wide range in simulated loss of near-surface permafrost area to historical climate change between 1960 and the end of each simulation ( -0.2 to $-59.8 \times 10^{3} \mathrm{~km}^{2} \mathrm{yr}^{-1}$ loss). With respect to the exposure to climate change, each of the modeling teams in this study was allowed to choose its own climate driving data. There is little variability in the trends of air temperature $\left(+0.03\right.$ to $\left.+0.04{ }^{\circ} \mathrm{Cyr}^{-1}\right)$ in the forcing data sets used to drive the models; i.e., the models' exposure to warming is similar. Although we find that the trend in $20 \mathrm{~cm}$ simulated soil temperature is related to trend in long-wave radiation among the models that use long-wave radiation as a driver [Peng et al., 2015], the change in permafrost area is not related to the trend in long-wave radiation. Thus, we infer from this study that the variability in simulated changes of permafrost area as depicted in the models depends more on differences in the sensitivity of the models to historical climate change rather than on differences in the forcing data sets. For example, it is clear that snow insulation differences, such as those between GIPLa and GIPLb, can make substantial differences in the estimated rate of permafrost area loss; we have more completely analyzed the effects of different implementations of snow insulation effects (not shown) and conclude that a well-simulated snow insulation is a condition for accurate simulation of permafrost area and soil thermal dynamics [see also Lawrence and Slater, 2010; Lawrence et al., 2012].

The sensitivity experiments we conducted revealed different sensitivities of permafrost area to historical changes in climate. While the simulated change in permafrost area of all of the models is sensitive to changes in temperature, interactions among changes in temperature, precipitation, and atmospheric $\mathrm{CO}_{2}$ play a substantial role in all but two models (CLM4.5 and ORCHb). We were not able to elucidate why interactions tended to promote the loss of permafrost in some models but retard the loss in others. General structural differences among the models (the depth of simulation, the consideration of organic horizon insulation, the number of layers of snow insulation, and the consideration of unfrozen water on phase change) do not explain the variability in the simulated changes in permafrost area. Structural differences also do not explain variability in the sensitivity of permafrost area to changes in air temperature, precipitation, atmospheric $\mathrm{CO}_{2}$, and their interactions. With respect to ALT, the models generally capture the observed relationship between ALT and climate. While additional diagnostics did identify reasons for some model-data mismatches for individual models, no single variable explains the bulk of differences among the models. However, this set of models does show reduced biases in soil thermal dynamics in comparison with models from the CMIP5 archive [Koven et al., 2013b]. We conclude that there is a need for the development of a 
comprehensive set of benchmarks so that modelers can diagnose and effectively improve models across the suite of issues affecting their sensitivity to changes in climate.

\subsection{The Sensitivity of Simulated Carbon in the Permafrost Region From 1960 to 2009}

Changes in atmospheric $\mathrm{CO}_{2}$ largely explain the simulated increases in vegetation $\mathrm{C}$ and soil $\mathrm{C}$ over the last 50 years. Given all other forcings equal, two of eight model simulations indicate that vegetation $C$ storage would have decreased in response to historical warming, and eight of nine model simulations indicate that soil $C$ storage would have decreased in response to warming. Thus, this study generally indicates that the simulated response of plant production to increases in atmospheric $\mathrm{CO}_{2}$ has promoted $\mathrm{C}$ storage in recent decades, while the response of decomposition to temperature has decreased $C$ storage in recent decades. The models vary in their sensitivity of $C$ storage to historical changes in precipitation, with much greater variation in the sensitivity of soil $C$ storage than vegetation $C$ storage. Disturbance also appears to be an important factor in the variability of simulated changes in $\mathrm{C}$ storage, as models that consider disturbance had lower increases in $\mathrm{C}$ storage than models that do not consider disturbance. This is consistent with the analysis of Hayes et al. [2011] that increases in the frequency of fire disturbance may be weakening the terrestrial sink in northern high-latitude regions. Finally, models that considered methane emissions and lateral transfers of $C$ tended to be weaker sinks. This is consistent with modeling study of McGuire et al. [2010a], in which increasing methane emissions and lateral losses of DOC decreased sink strength of terrestrial ecosystems in the drainage basin of the Arctic Ocean between 1997 and 2006 [see also Kicklighter et al., 2013].

Although the response to $\mathrm{CO}_{2}$ fertilization is the primary reason for increases in $\mathrm{C}$ storage simulated by the models, there is a large range of sensitivity of both vegetation and soil $\mathrm{C}$ storage to increases in atmospheric $\mathrm{CO}_{2}$. The importance of $\mathrm{CO}_{2}$ fertilization in affecting simulated $\mathrm{C}$ storage has been noted in several comparisons among large-scale biogeochemistry models [Kicklighter et al., 1999; McGuire et al., 2001; Sokolov et al., 2008; Sitch et al., 2008; Piao et al., 2013]. Previous model comparisons have indicated that changes in C inputs are largely responsible for simulated changes in C storage [Todd-Brown et al., 2014] and that in particular, the sensitivity of plant productivity to changes in $\mathrm{CO}_{2}$ concentration is the key issue to constrain with respect to constraining the sink strength simulated by models [Hajima et al., 2014]. The sensitivities of model responses to changes in atmospheric $\mathrm{CO}_{2}$ in global-scale applications have been compared to results from free-air exchange $\mathrm{CO}_{2}$ enrichment (FACE) experiments, where ecosystems are exposed to a much higher $\mathrm{CO}_{2}$ level than the historical increase [Piao et al., 2013], and the NPP of models is slightly more sensitive (16\% per 100 ppmv increase) than indicated by experimental studies (13\% per 100 ppmv increase). In this study, the mean NPP increase over the permafrost region estimated from the $\mathrm{CO}_{2}$ sensitivity analysis was $16 \%$ per 100 ppmv increase among the models (range: 3 to 26\%). It is noteworthy that only two of the models (CLM4.5 at 3\% and TEM6 at 11\%) were less than the mean of the experimental studies (13\%) reported by Piao et al. [2013] and that these were the only models for which C uptake was limited by plant $\mathrm{N}$ dynamics. Although the importance of implementing $\mathrm{N}$ limitation on $\mathrm{C}$ uptake in global biogeochemical models was first raised in the early 1990s [McGuire et al., 1992], it has only been on the agenda of most Earth system models since the study of Sokolov et al. [2008], and progress has generally been slow. Given that the $\mathrm{CO}_{2}$ response of northern high-latitude ecosystems is expected to be quite damped because plant production in the region is very limited by N availability [McGuire et al., 1995, 1997], as a group NPP simulated by the models in this study appears to be overly sensitive to increases in atmospheric $\mathrm{CO}_{2}$. Unfortunately, there have not been substantive FACE experiments in northern high-latitude ecosystems that can be used for evaluation of model sensitivities to changes in atmospheric $\mathrm{CO}_{2}$ in the permafrost region.

In general, changes in surface soil temperature are relevant to the decomposition of soil $\mathrm{C}$ in all of the models in this study. Simulated changes in permafrost area, which are indicative of a thickening of the active layer, are relevant to the exposure of soil $\mathrm{C}$ in previously frozen soil to decomposition. The increases in soil $\mathrm{C}$ of the model simulations in this study that explicitly represent soil $C$ with depth ( 6 of 13 simulations) were not significantly less than the other models in the study. In the model experiments we conducted, ORCHa is the only model to have a positive sensitivity of soil $\mathrm{C}$ to warming. However, $\mathrm{ORCHb}$, which simulates soil $\mathrm{C}$ to a deeper depth than $\mathrm{ORCHa}$, has a negative sensitivity. Overall, our analysis suggests that the large variability in the sensitivity of changes in simulated soil C storage to different drivers may mask the relative importance of representing soil $C$ with depth. In addition, we believe that the changes in forcing analyzed in this study were not large enough to reveal the importance of representing soil carbon with depth and that it will 
require analyses of the sensitivity of the models to projected changes in climate to better evaluate this structural issue.

The sensitivity of soil $C$ to different drivers is influenced by the sensitivity of inputs into the soil. Over decadal time periods, changes in inputs to the soil are substantially driven by changes in NPP in response to drivers. Notably, changes in vegetation C are also intimately coupled with changes in NPP among the models in this study. The change in NPP among the model simulations in this study is largely caused by the change in GPP. In addition, GPP simulated by the models is overestimated at both site and by biases in the seasonal maximum (i.e., July) GPP simulated among the models (analysis not shown). Other syntheses have shown that GPP simulated by process-based models over North America is generally biased low because of biases in simulating canopy phenology [Richardson et al., 2012; Schaefer et al., 2012b]. Rawlins et al. [2015] found substantial underestimates in the seasonal simulation of GPP in the boreal region of northern Eurasia among the models analyzed in this study, and Euskirchen et al. [2014] has shown that improvements in the modeling of canopy phenology alters simulated structure and function in tundra ecosystems of Alaska. It is also important to note that other studies have concluded that process-based models overestimate ecosystem/heterotrophic respiration in boreal regions of northern Eurasia in recent decades [Quegan et al., 2011; Dolman et al., 2012], including the models in this study [Rawlins et al., 2015], which may be another reason why process-based models tend to underestimate the sink strength of the permafrost region in comparison to analyses of atmospheric inversion models.

Our analysis of GPP trends between 1960 and 2009 indicates that all of the models overestimate trends in GPP compared with trends in the JU11 global GPP product. Because the JU11 product depends on relationships between the limited eddy covariance data in the permafrost region and fraction of absorbed photosynthetically active radiation, which are used to extrapolate GPP spatially and temporally back to 1982 [Jung et al., 2011], some caution must be exercised in interpreting the lack of a trend in the product. However, the interannual variability of the JU11 product is well correlated with the Moderate Resolution Imaging Spectroradiometer (MODIS) GPP product from 2000 to 2009 over the permafrost region $(R=0.78$, $P=0.007, N=10$ ), and neither the JU11 nor the MODIS GPP products have significant trends over the 2000-2009 time period over this region. Because the GPP trend in all of the models is substantially influenced by increases in atmospheric $\mathrm{CO}_{2}$ (accounting for 40 to $80 \%$ of the response; analysis not shown), it is particularly important to constrain the response of simulated GPP to changes in atmospheric $\mathrm{CO}_{2}$. Furthermore, the responses of GPP to changes in temperature and precipitation are quite variable among the models but can contribute up to $50 \%$ of the response of GPP. Thus, it is also important to make progress in constraining the response of simulated GPP to changes in temperature and precipitation.

\section{Conclusions}

Based on the previous discussion and additional discussion below, in Table 9 we summarize our thoughts on the improvement of models that are used to assess the responses of permafrost and $C$ in the permafrost region to climate change. The improvements we suggest concern (1) the need to implement/harmonize/ benchmark permafrost and biogeochemical structural issues and (2) the need to constrain/benchmark key biogeochemical processes in these models. With respect to structural representation of permafrost dynamics, our analyses did not find that individual structural differences in Table 1 explained responses across models. In part, this may be because the changes in forcing analyzed in this study were not large enough to reveal the importance of structural differences. This argues for analyses of the sensitivity of the models to projected changes in climate. Another confounding factor is that the models are quite variable in the structural representation of the soil and whether or not they represent potential processes that could influence soil thermal dynamics (e.g., unfrozen water dynamics). Other studies have indicated that it is important to represent thermal dynamics in soils to between 50 and $100 \mathrm{~m}$ [Alexeev et al., 2007; Nicolsky et al., 2007; Saito, 2008], moss insulation [Zhuang et al., 2002], organic horizon insulation [Nicolsky et al., 2007; Saito, 2008; Lawrence et al., 2008; Koven et al., 2009; Jafarov et al., 2013], and the effects of unfrozen water on phase change [Romanovsky and Osterkamp, 2000; Nicolsky et al., 2007; Saito, 2008]. There are also substantial differences among models with respect to how they represent snow insulation [Lawrence and Slater, 2010; Gouttevin et al., 2012a; Slater and Lawrence, 2013] that need to be resolved. If more models can effectively address these issues of soil column depth, moss and organic horizon insulation, unfrozen water, and snow insulation, then the modeling community will be better able to identify 
Table 9. Summary of Permafrost and Biogeochemical Structural Issues to Implement/Harmonize/Benchmark and Key Biogeochemical Processes to Constrain/ Benchmark in Earth System Models That Are Used to Assess the Permafrost Carbon Feedback

Key Structural or Process Issue

Justification

Permafrost structure

Depth of soil column 50 to $100 \mathrm{~m}$

Moss insulation

Organic horizon insulation

Effects of unfrozen water on soil thermal dynamics

Snow insulation

Alexeev et al. [2007], Nicolsky et al. [2007], and Saito [2008]

Zhuang et al. [2002]

Nicolsky et al. [2007], Saito [2008], Lawrence et al. [2008], Koven et al. [2009], and Jafarov et al. [2013]

Romanovsky and Osterkamp [2000], Nicolsky et al. [2007], and Saito [2008]

Lawrence and Slater [2010], Gouttevin et al. [2012a], and Slater and Lawrence [2013]

Biogeochemical structure

Representation of soil $\mathrm{C}$ with depth and segregated into organic and mineral horizons

Loss of $\mathrm{C}$ through $\mathrm{CH}_{4}$ emissions

Loss of $C$ through wildfire

Loss of $C$ through lateral transfers

Influence of $\mathrm{N}$ availability on $\mathrm{C}$ uptake

Biogeochemical process issues

Sensitivity of GPP to $\mathrm{CO}_{2}$ fertilization

Canopy phenology

Ecosystem/heterotrophic respiration

Yi et al. [2009, 2010], Schaefer et al. [2011], Yuan et al. [2012], Hugelius [2012],

Harden et al. [2012], and Koven et al. [2013a, 2015]

This study and McGuire et al. [2010a]

This study and Hayes et al. [2011]

This study, McGuire et al. [2010a], and Kicklighter et al. [2013]

Inferred from this study, McGuire et al. [1995, 1997], Kicklighter et al. [1999], and Sokolov et al. [2008]

Sensitivity of heterotrophic respiration in organic and

mineral horizons to temperature and soil moisture

This study and numerous global-scale studies

Rawlins et al. [2015], Euskirchen et al. [2014], Richardson et al. [2012], and Schaefer et al. [2012b]

Rawlins et al. [2015], Quegan et al. [2011], and Dolman et al. [2012]

Olefeldt et al. [2013], Schädel et al. [2013], and Treat et al. [2015]

issues of mathematical formulation and parameterization that explain differences among permafrost dynamics simulated by models.

Although we did not find that the explicit representation of soil $\mathrm{C}$ with depth to be an issue that differentiated responses among models, it is likely to be an issue in the future response of models [Schaefer et al., 2011]. Other analyses indicate that substantially more soil $C$ is likely to be exposed in the future from permafrost thaw [Harden et al., 2012]. While it is a challenge to explicitly represent soil C with depth in large-scale models, it is an important issue to address for credibility of assessments of $C$ dynamics in the permafrost region. It is now feasible to address this challenge because of the recent progress in developing new soil $\mathrm{C}$ databases for the permafrost region [Hugelius, 2012; Harden et al., 2012]. In fact, substantial progress has been made in modeling the dynamics of $\mathrm{C}$ in organic and mineral soil horizons of ecosystems with permafrost [ $Y$ i et al., 2009, 2010; Yuan et al., 2012]. Other structural issues also need to be harmonized among models used to assess the permafrost carbon feedback. As our analysis indicates that losses of $\mathrm{C}$ from $\mathrm{CH}_{4}$ emissions, wildfire, and lateral transfers led to lower $\mathrm{C}$ accumulation in models that considered these processes, we also suggest that models represent losses of $C$ through all of these pathways. As production in northern high-latitude ecosystems is substantially limited by N availability [McGuire et al., 1992], a prerequisite to constraining the sensitivity of GPP to both $\mathrm{CO}_{2}$ and temperature in models will likely require that models used to assess the permafrost carbon feedback structurally represent interactions between $\mathrm{C}$ and $\mathrm{N}$ dynamics.

With respect to differences among models that influence the sensitivity of $C$ in the permafrost region, our analysis suggests that the response of GPP to atmospheric $\mathrm{CO}_{2}$ fertilization is the most important issue to constrain. The sensitivity of GPP to temperature change is the second most important issue to constrain, and this will likely require improvements in modeling canopy phenology. Once models effectively represent the structure of soil $\mathrm{C}$ in permafrost ecosystems, they will then be able to improve the modeling of heterotrophic respiration and the fate of soil $\mathrm{C}$ in newly thawed permafrost. In particular, models can then make effective use of information to constrain heterotrophic respiration from recent syntheses of soil incubation experiments that have revealed the environmental sensitivities of soil $C$ through aerobic and anaerobic pathways in both organic and mineral horizons [Olefeldt et al., 2013; Schädel et al., 2013; Treat et al., 2015].

The implementation of appropriate structure and the evaluation of processes in models used to evaluate the permafrost carbon feedback will require additional progress in benchmarking the models with respect to their responses of permafrost and $C$ to changes in climate. For permafrost, we presented diagnostic analyses that we conducted in this study (i.e., ALT versus climate in Figure 3; see also Figures S1-S6). Our evaluation of the simulation of GPP identified that more data are needed to effectively evaluate whether the responses of 
models to $\mathrm{CO}_{2}$ fertilization are within acceptable bounds. There is also substantial opportunity to pull together data from observation networks in the permafrost region; many of which were set up in the middle to late 2000s as part of the International Polar Year to provide benchmarking data sets for a number of variables including soil temperature, thaw depth, active layer thickness, soil C stocks, vegetation $C$ stocks, and C fluxes. It is important to recognize that while documenting biases in key model outputs is important, it is more important to understand the degree to which the sensitivity of permafrost and of $C$ pools and fluxes to changes in climate is accurate. Functional benchmarks, such as the ALT versus climate analysis we presented in this study, are more helpful in identifying biases in sensitivity relevant to model dynamics than direct comparisons of ALT between observations and model output. Benchmark data sets with temporal dynamics that can be used to evaluate model variability at various time scales from seasonal to multidecadal are needed to evaluate model responses in the permafrost region to environmental variability at all of these scales.

Finally, it should be noted that the models analyzed in this study do not consider some processes that may affect the loss of permafrost and the permafrost carbon feedback. For example, it has recently been proposed that long-term shifts in vegetation cover following summer warming ultimately lead to a cooling of the arctic tundra summer soil temperature [Sistla et al., 2013] and that this may tend to stabilize soil carbon. Also, the thawing of ice-rich permafrost [e.g., Liljedahl et al., 2016] generally causes surface subsidence, i.e., thermokarst, which drives landscape transitions that could substantially influence carbon dynamics [e.g., Lara et al., 2015; O'Donnell et al., 2012]. The modeling of thermokarst and its effects on carbon dynamics at large spatial scales has only recently been implemented in simple Earth system models [Schneider von Deimling et al., 2015]. We caution that the effects of these newly appreciated processes on the permafrost carbon feedback cannot be effectively addressed by models until those models have harmonized the aforementioned structural issues and adequately constrained key processes such as the sensitivity of GPP to increasing atmospheric $\mathrm{CO}_{2}$.

Acknowledgments

Support for this study was provided by the National Science Foundation through the Research Coordination Network program and through the Study of Environmental Arctic Change program, the U.S. Geological Survey, the U.S. Department of Energy Office of Science (Biological and Environmental Research), the University of Victoria, NSERC CGS, NSERC CREATE, Joint DECC/Defra Met Office Hadley Centre Climate Programme (GA01101), the European Union FP7-ENVIRONMENT project PAGE21, the program CLASSIQUE of the French "Agence Nationale pour la Recherche," the Program for Risk Information on Climate Change, MEXT, Japan, the Modeling the Regional and Global Earth System activity, and the Lund University Centre for the study of Climate and Carbon Cycle. Any use of trade, firm, or product names is for descriptive purposes only and does not imply endorsement by the U.S. Government. The simulation data analyzed in this manuscript is available through the National Snow and Ice Data Center through e-mail request to Kevin Schaefer (kevin.schaefer@nsidc.org).

\section{References}

Alexeev, V., D. Nicolsky, V. Romanovsky, and D. Lawrence (2007), An evaluation of deep soil configurations in the CLM3 for improved representation of permafrost, Geophys. Res. Lett., 34, L09502, doi:10.1029/2007GL029536.

Avis, C. A., A. J. Weaver, and K. J. Meissner (2011), Reduction in areal extent of high-latitude wetlands in response to permafrost thaw, Nat. Geosci., 4, 444-448, doi:10.1038/ngeo1160.

Balshi, M. S., A. D. McGuire, P. Duffy, M. Flannigan, J. Walsh, and J. Melillo (2009), Assessing the response of area burned to changing climate in western boreal North America using a Multivariate Adaptive Regression Splines (MARS) approach, Global Change Biol., 15, 578-600, doi:10.1111/j.1365-2486.2008.01679.x.

Beer, C., U. Weber, E. Tomelleri, N. Carvalhais, M. Mahecha, and M. Reichstein (2014), Harmonized European long-term climate data for assessing the effect of change temporal variability on land-atmosphere $\mathrm{CO}_{2}$ fluxes, J. Clim., 27, 4815-4834, doi:10.1175/JCLI-D-13-00543.1.

Belshe, E. F., E. A. G. Schuur, and B. Bolker (2013), Tundra ecosystems observed to be $\mathrm{CO}_{2}$ sources due to differential amplification of the carbon cycle, Ecol. Lett., 16, 1316-1324, doi:10.1111/ele.12164.

Best, M. J., et al. (2011), The Joint UK Land Environment Simulator (JULES), model description—Part 1: Energy and water fluxes, Geosci. Model Dev., 4, 677-699, doi:10.5194/gmd-4-677-2011.

Bohn, T. J., B. Livneh, J. W. Oyler, S. W. Running, B. Nijssen, and D. P. Lettenmaier (2013a), Global evaluation of MTCLIM and related algorithms for forcing of ecological and hydrological models, Agric. For. Meteorol., 176, 38-49, doi:10.1016/j.agrformet.2013.03.003.

Bohn, T. J., et al. (2013b), Modeling the large-scale effects of surface moisture heterogeneity on wetland carbon fluxes in the West Siberian Lowland, Biogeosciences, 10, 6559-6576, doi:10.5194/bg-10-6559-2013.

Brown, J., O. J. Ferrians Jr., J. A. Heginbottom, and E. S. Melnikov (1998), Circum-Arctic Map of Permafrost and Ground-Ice Conditions, Natl. Snow and Ice Data Cent./World Data Cent. for Glaciol., Digital Media, Boulder, Colo.

Brown, J., K. Hinkel, and F. Nelson (2000), The Circumpolar Active Layer Monitoring (CALM) program: Research designs and initial results, Polar Geogr., 24, 165-258, doi:10.1080/10889370009377698.

Burke, E. J., I. P. Hartley, and C. D. Jones (2012), Uncertainties in the global temperature change caused by carbon release from permafrost thawing, Cryosphere, 6, 1063-1076, doi:10.5194/tc-6-1063-2012.

Burke, E. J., C. D. Jones, and C. D. Koven (2013), Estimating the permafrost-carbon climate response in the CMIP5 climate models using a simplified approach, J. Clim., 26, 4897-4909, doi:10.1175/JCLI-D-12-00550.1.

Chapin, F. S., III, et al. (2006), Reconciling carbon-cycle concepts, terminology, and methods, Ecosystems, 9, 1041-1050.

Chapin, F. S., III, J. T. Randerson, A. D. McGuire, J. A. Foley, and C. B. Field (2008), Changing feedbacks in the climate-biosphere system, Front. Ecol. Environ., 6, 313-320, doi:10.1890/080005.

Chen, X. T., J. Bohn, and D. P. Lettenmaier (2015), Model estimates of climate controls on pan-Arctic wetland methane emissions, Biogeosciences, 12, 6259-6277, doi:10.5194/bg-12-6259-2015.

Clark, D. B., et al. (2011), The Joint UK Land Environment Simulator (JULES), model description—Part 2: Carbon fluxes and vegetation dynamics, Geosci. Model Dev., 4, 701-722, doi:10.5194/gmd-4-701-2011.

Dai, Y., et al. (2003), The Common Land Model (CLM), Bull. Am. Meteorol. Soc., 84, 1013-1023, doi:10.1175/BAMS-84-8-1013.

Dai, Y., R. E. Dickinson, and Y.-P. Wang (2004), A two-big-leaf model for canopy temperature, photosynthesis, and stomatal conductance, J. Clim., 17, 2281-2299, doi:10.1175/1520-0442(2004)017<2281:ATMFCT >2.0.CO;2.

Decharme, B., A. Boone, C. Delire, and J. Noilhan (2011), Local evaluation of the interaction between Soil Biosphere Atmosphere soil multilayer diffusion scheme using four pedotransfer functions, J. Geophys. Res., 116, D20126, doi:10.1029/2011JD016002. 
Decharme, B., E. Martin, and S. Faroux (2013), Reconciling soil thermal and hydrological lower boundary conditions in land surface models, J. Geophys. Res. Atmos., 118, 7819-7834, doi:10.1002/jgrd.50631.

Dolman, A. J., et al. (2012), An estimate of the terrestrial carbon budget of Russia using inventory-based, eddy covariance and inversion methods, Biogeosciences, 9, 5323-5340, doi:10.5194/bg-9-5323-2012.

Ekici, A., C. Beer, S. Hagemann, J. Boike, M. Langer, and C. Hauck (2014), Simulating high-latitude permafrost regions by the JSBACH terrestrial ecosystem model, Geosci. Model Dev., 7, 631-647, doi:10.5194/gmd-7-631-2014.

Euskirchen, E. S., T. B. Carman, and A. D. McGuire (2014), Changes in the structure and function of northern Alaskan ecosystems when considering variable leaf-out times across groupings of species in a dynamic vegetation model, Global Change Biol., 20, 963-978, doi:10.1111/gcb.12392.

Flannigan, M. D., Y. Bergeron, O. Engelmark, and B. M. Wotton (1998), Future wildfire in circumboreal forests in relation to global warming, J. Veg. Sci., 9, 469-476.

Fyfe, J. C., K. von Salzen, N. P. Gillett, V. K. Arora, G. M. Flato, and J. R. McConnell (2013), One hundred years of Arctic surface temperature variation due to anthropogenic influence, Sci. Rep., 3, 2645, doi:10.1038/srep02645.

Genet, H., et al. (2013), Modeling the effects of fire severity and climate warming on active layer thickness and soil carbon storage of black spruce forests across the landscape in interior Alaska, Environ. Res. Lett., 8, 13, doi:10.1088/1748-9326/8/4/045016.

Goll, D. S., V. Brovkin, J. Liski, T. Raddatz, T. Thum, and K. E. O. Todd-Brown (2015), Strong dependence of $\mathrm{CO}_{2}$ emissions from anthropogenic land cover change on initial land cover and soil carbon parametrization, Global Biogeochem. Cycles, 29, 1511-1523, doi:10.1002/2014GB004988.

Gouttevin, I., M. Menegoz, F. Domine, G. Krinner, C. D. Koven, P. Ciais, C. Tarnocai, and J. Boike (2012a), How the insulating properties of snow affect soil carbon distribution in the continental pan-Arctic area, J. Geophys. Res., 117, G02020, doi:10.1029/2011JG001916.

Gouttevin, I., G. Krinner, P. Ciais, J. Polcher, and C. Legout (2012b), Multi-scale validation of a new soil freezing scheme for a land-surface model with physically-based hydrology, Cryosphere, 6, 407-430, doi:10.5194/tc-6-407-2012.

Hajima, T., K. Tachiiri, A. Ito, and M. Kawamiya (2014), Uncertainty of concentration-terrestrial carbon feedback in Earth system models, J. Clim., 27, 3425-3445, doi:10.1175/JCLI-D-13-00177.1.

Harden, J. W., E. T. Sundquist, R. F. Stallard, and R. K. Mark (1992), Dynamics of soil carbon during deglaciation of the Laurentide ice sheet, Science, 258, 1921-1924.

Harden, J. W., et al. (2012), Field information links permafrost carbon to physical vulnerabilities of thawing, Geophy. Res. Lett., 39, L15704, doi:10.1029/2012GL051958.

Harris, I., P. D. Jones, T. J. Osborn, and D. H. Lister (2014), Updated high-resolution grids of monthly climatic observations-the CRU TS3.10 Dataset, Int. J. Climatol., 34, 623-642, doi:10.1002/joc.3711.

Hayes, D. J., D. A. McGuire, D. W. Kicklighter, K. R. Gurney, T. J. Burnside, and J. M. Melillo (2011), Is the northern high latitude land-based $\mathrm{CO}_{2}$ sink weakening?, Global Biogeochem. Cycles, 25, GB3018, doi:10.1029/2010GB003813.

Hayes, D. J., D. W. Kicklighter, A. D. McGuire, M. Chen, Q. Zhuang, F. Yuan, J. M. Melillo, and S. D. Wullschleger (2014), The impacts of recent permafrost thaw on land-atmosphere greenhouse gas exchange, Environ. Res. Lett., 9, doi:10.1088/1748-9326/9/4/045005.

Hugelius, G. (2012), Spatial upscaling using thematic maps: An analysis of uncertainties in permafrost soil carbon estimates, Global Biogeochem. Cycles, 26, GB2026, doi:10.1029/2011gb004154.

Jafarov, E. E., V. E. Romanovsky, H. Genet, A. D. McGuire, and S. S. Marchenko (2013), The effects of fire on the thermal stability of permafrost in lowland and upland black spruce forests of interior Alaska in a changing climate, Environ. Res. Lett., 8, doi:10.1088/1748-9326/8/3/035030.

Ji, D., et al. (2014), Description and basic evaluation of Beijing Normal University Earth system model (BNU-ESM) version 1, Geosci. Model Dev., 7, 2039-2064, doi:10.5194/gmd-7-2039-2014.

Jung, M., et al. (2011), Global patterns of land-atmosphere fluxes of carbon dioxide, latent heat, and sensible heat derived from eddy covariance, satellite, and meteorological observations, J. Geophys. Res., 117, G00J07, doi:10.1029/2010JG001566.

Kicklighter, D. W., et al. (1999), A first-order analysis of the potential role of $\mathrm{CO}_{2}$ fertilization to affect the global carbon budget: A comparison of four terrestrial biosphere models, Tellus, 51B, 343-366.

Kicklighter, D. W., D. J. Hayes, J. W. McClelland, B. J. Peterson, A. D. McGuire, and J. M. Melillo (2013), Insights and issues with simulating terrestrial DOC loading of arctic river networks, Ecol. Appl., 23, 1817-1836.

Koven, C., P. Friedlingstein, P. Ciais, D. Khvorostyanov, G. Krinner, and C. Tarnocai (2009), On the formation of high-latitude soil carbon stocks: Effects of cryoturbation and insulation by organic matter in a land surface model, Geophys. Res. Lett., 36, L21501, doi:10.1029/ 2009GL040150.

Koven, C. D., B. Ringeval, P. Friedlingstein, P. Ciais, P. Cadule, D. Khvorostyanov, G. Krinner, and C. Tarnocai (2011), Permafrost carbon-climate feedbacks accelerate global warming, Proc. Natl. Acad. Sci. U.S.A., 108, 14,769-14,774, doi:10.1073/pnas.1103910108.

Koven, C. D., W. J. Riley, Z. M. Subin, J.-Y. Tang, M. S. Torn, W. D. Collins, G. B. Bonan, D. M. Lawrence, and S. C. Swenson (2013a), The effect of vertically-resolved soil biogeochemistry and alternate soil C and N models on C dynamics of CLM4, Biogeosciences, 10, doi:10.5194/bg-107109-2013.

Koven, C. D., W. J. Riley, and A. Stern (2013b), Analysis of permafrost thermal dynamics and response to climate change in the CMIP5 Earth system model, J, Climate, 26, 1877-1900, doi:10.1175/JCLI-D-12-00228.1.

Koven, C. D., et al. (2015), A simplified, data-constrained approach to estimate the permafrost carbon-climate feedback, Philos. Trans. R. Soc. London, Ser. A, 373, 20140423, 23, doi:10.1098/rsta.2014.0423.

Lara, M. J., A. D. McGuire, E. S. Euskirchen, C. E. Tweedie, K. M. Hinkel, A. N. Skurikhin, V. E. Romanovsky, G. Grosse, W. R. Bolton, and H. Genet (2015), Polygonal tundra geomorphological change in response to warming alters future $\mathrm{CO}_{2}$ and $\mathrm{CH}_{4}$ flux on the Barrow Peninsula, Global Change Biol., 21, 1634-1651, doi:10.1111/gcb.12757.

Lawrence, D. M., and A. G. Slater (2010), The contribution of snow condition trends to future ground climate, Clim. Dyn., 34, 969-981, doi:10.1007/s00382-009-0537-4.

Lawrence, D. M., A. G. Slater, V. E. Romanovsky, and D. J. Nicolsky (2008), The sensitivity of a model projection of near-surface permafrost degradation to soil column depth and inclusion of soil organic matter, J. Geophys. Res., 113, F02011, doi:10.1029/2007JF000883.

Lawrence, D. M., A. G. Slater, and S. Swenson (2012), Simulation of present-day and future permafrost and seasonally frozen ground conditions in CCSM4, J. Clim., 25, 2207-2225, doi:10.1175/JCLI-D-11-00334.1.

Liljedahl, A. K., et al. (2016), Pan-Arctic ice-wedge degradation in warming permafrost and its influence on tundra hydrology, Nat. Geosci., 9, 312-318, doi:10.1038/ngeo2674.

Luo, Y., et al. (2016), Toward more realistic projections of soil carbon dynamics by Earth system models, Global Biogeochem. Cycles, 30, 40-56, doi:10.1002/2015GB005239.

MacDougall, A. H., C. A. Avis, and A. J. Weaver (2012), Significant existing commitment to warming from the permafrost carbon feedback, Nat. Geosci., 5, 719-721, doi:10.1038/NGEO1573. 
Mack, M. C., M. S. Bret-Harte, T. N. Hollingsworth, R. R. Jandt, E. A. G. Schuur, G. R. Shaver, and D. L. Verbyla (2011), Carbon loss from an unprecedented tundra wildfire, Nature, 475, 489-492.

Marchenko, S., V. Romanovsky, and G. Tipenko (2008), Numerical modeling of spatial permafrost dynamics in Alaska, in Proceedings of the Ninth International Conference on Permafrost, vol. 2, edited by D. Kane and K. Hinkel, pp. 1125-1130, Univ. of Alaska Fairbanks, Fairbanks.

McGuire, A. D., J. M. Melillo, L. A. Joyce, D. W. Kicklighter, A. L. Grace, B. Moore III, and C. J. Vorosmarty (1992), Interactions between carbon and nitrogen dynamics in estimating net primary productivity for potential vegetation in North America, Global Biogeochem. Cycles, 6 , 101-124, doi:10.1029/92GB00219.

McGuire, A. D., J. M. Melillo, and L. A. Joyce (1995), The role of nitrogen in the response of forest net primary production to elevated atmospheric carbon dioxide, Ann. Rev. Ecol. Sys., 26, 473-503.

McGuire, A. D., J. M. Melillo, D. W. Kicklighter, Y. Pan, X. Xiao, J. Helfrich, B. Moore III, C. J. Vorosmarty, and A. L. Schloss (1997), Equilibrium responses of global net primary production and carbon storage to doubled atmospheric carbon dioxide: Sensitivity to changes in vegetation nitrogen concentration, Global Biogeochem. Cycles, 11, 173-189, doi:10.1029/97GB00059.

McGuire, A. D., et al. (2001), Carbon balance of the terrestrial biosphere in the twentieth century: Analyses of $\mathrm{CO}_{2}$, climate and land-use effects with four process-based ecosystem models, Global Biogeochem. Cycles, 15, 183-206, doi:10.1029/2000GB001298.

McGuire, A. D., L. G. Anderson, T. R. Christensen, S. Dallimore, L. Guo, D. J. Hayes, M. Heimann, T. D. Lorenson, R. W. Macdonald, and N. Roulet (2009), Sensitivity of the carbon cycle in the Arctic to climate change, Ecol. Monogr., 79, 523-555.

McGuire, A. D., et al. (2010a), An analysis of the carbon balance of the Arctic Basin from 1997 to 2006, Tellus, 62B, 455-474, doi:10.1111/j.16000889.2010.00497.x.

McGuire, A. D., R. W. Macdonald, E. A. G. Schuur, J. W. Harden, P. Kuhry, D. J. Hayes, T. R. Christensen, and M. Heimann (2010b), The carbon budget of the northern cryosphere region, Curr. Opin. Environ. Sustain., 2, 231-236, doi:10.1016/j.Cosust.2010.05.003.

McGuire, A. D., et al. (2012), An assessment of the carbon balance of arctic tundra: Comparisons among observations, process models, and atmospheric inversions, Biogeosciences, 9, 3185-3204, doi:10.5194/bg-9-3185-2012.

Miller, P. A., and B. Smith (2012), Modelling tundra vegetation response to recent arctic warming, Ambio, 41(Suppl. 3), 281-291, doi:10.1007/ s13280-012-0306-1.

Mitchell, T. D., and P. D. Jones (2005), An improved method of constructing a database of monthly climate observations and associated high-resolution grids, Int. J. Climatol., 25, 693-712, doi:10.1002/joc.1181.

Nicolsky, D. J., V. E. Romanovsky, V. A. Alexeev, and D. M. Lawrence (2007), Improved modeling of permafrost dynamics in a GCM land-surface scheme, Geophys. Res. Lett., 34, L08501, doi:10.1029/2007GL029525.

Nicolsky, D. J., V. E. Romanovsky, and G. G. Panteleev (2009), Estimation of soil thermal properties using in-situ temperature measurements in the active layer and permafrost, Cold Reg. Sci. Technol., 55, 120-129.

O'Donnell, J. A., M. T. Jorgenson, J. W. Harden, A. D. McGuire, M. Z. Kanevskiy, and K. P. Wickland (2012), The effects of permafrost thaw on soil hydrologic, thermal and carbon dynamics in an Alaskan peatland, Ecosystems, 15, 213-229, doi:10.1007/s10021-011-9504-0.

Olefeldt, D., M. R. Turetsky, P. M. Crill, and A. D. McGuire (2013), Environmental and physical controls on northern high latitude methane fluxes across permafrost zones, Global Change Biol., 19, 589-603, doi:10.1111/gcb.12071.

Oleson, K. W., et al. (2013), Technical description of version 4.5 of the Community Land Model (CLM), Natl. Cent. for Atmos. Res., Tech. Note NCAR/TN-503+STR

Pan, Y., et al. (2011), A large and persistent carbon sink in the world's forests, Science, 333, 988-993, doi:10.1126/science.1201609.

Peng, S., et al. (2015), Simulated high-latitude soil thermal dynamics during the past four decades, Cryosphere Disc., 9, 2301-2337, doi:10.5194/tcd-9-2301-2015.

Piao, S., et al. (2013), Evaluation of terrestrial carbon cycle models for their response to climate variability and to $\mathrm{CO}_{2}$ trends, $\mathrm{Global}$ Change Biol., 19, 2117-2132, doi:10.1111/gcb.12187.

Pithan, F., and T. Mauritsen (2014), Arctic amplification dominated by temperature feedbacks in contemporary climate models, Nat. Geosci., 7, 181-184, doi:10.1038/ngeo2071.

Qian, H., R. Joseph, and N. Zeng (2010), Enhanced terrestrial carbon uptake in the northern high latitudes in the 21 st century from the Coupled Carbon Cycle Climate Model Intercomparison Project model projections, Global Change Biol., 16, 641-656.

Quegan, S., C. Beer, A. Shvidenko, I. McCallum, I. C. Handoh, P. Peylin, P. C. Roedenbeck, W. Lucht, S. Nilsson, and C. Schmullius (2011), Estimating the carbon balance of central Siberia using a landscape-ecosystem approach, atmospheric inversion and dynamic global vegetation models, Global Change Biol., 17, 351-365.

Rawlins, M., et al. (2015), Assessment of model estimates of land-atmosphere $\mathrm{CO}_{2}$ exchange across northern Eurasia, Biogeosciences, 12 , 4385-4405, doi:10.5194/bg-12-1-2015.

Richardson, A. D., et al. (2012), Terrestrial biosphere models need better representation of vegetation phenology: Results from the North American Carbon Program site synthesis, Global Change Biol., 18, 566-584, doi:10.1111/j.1365-2486.2011.02562.x.

Romanovsky, V. E., and T. E. Osterkamp (2000), Effects of unfrozen water on heat and mass transport processes in the active layer and permafrost, Permafrost Periglacial Process, 11, 219-239, doi:10.1002/1099-1530(200007/09)11:3<219::AID-PPP352>3.0.CO;2-7.

Romanovsky, V. E., S. L. Smith, and H. H. Christiansen (2010), Permafrost thermal state in the polar Northern Hemisphere during the International Polar Year 2007-2009: A synthesis, Permafrost Periglacial Process, 21, 106-116, doi:10.1002/ppp.689.

Saito, K. (2008), Arctic land hydro-thermal sensitivity under warming: Idealized off-line evaluation of physical terrestrial scheme in a global climate model, J. Geophys. Res., 113, D21106, doi:10.1029/2008JD009880.

Schädel, C., E. A. G. Schuur, R. Bracho, B. Elberling, C. Knoblauch, H. Lee, Y. Luo, G. R. Shaver, and M. R. Turetsky (2013), Circumpolar assessment of permafrost $C$ quality and its vulnerability over time using long-term incubation data, Global Change Biol., doi:10.1111/gcb.12417.

Schaefer, K., A. S. Denning, N. Suits, J. Kaduk, I. Baker, S. Los, L. Prihodko (2002), Effect of climate on interannual variability of terrestrial CO fluxes, Global Biogeochem. Cycles, 16(4), 1102, doi:10.1029/2002GB001928.

Schaefer, K., T. Zhang, L. Bruhwiler, and A. P. Barrett (2011), Amount and timing of permafrost carbon release in response to climate warming, Tellus, 63B, 165-180.

Schaefer, K., H. Lantuit, V. E. Romanovsky, and E. A. G. Schuur (2012a), Policy implications of thawing permafrost, United Nations Environ. Programme Special Rep., ISBN: 978-92-807-3308-2, Job Number DEW/1621/NA, 30 pages.

Schaefer, K., et al. (2012b), A model-data comparison of gross primary productivity: Results from the North American Carbon Program site synthesis, J. Geophys. Res., 117, G03010, doi:10.1029/2012JG001960.

Schaefer, K., H. Lantuit, V. E. Romanovsky, E. A. G. Schuur, and R. Witt (2014), The impact of the permafrost carbon feedback on global climate, Environ. Res. Lett., 9, 085003, doi:10.1088/1748-9326/9/8/085003.

Schaphoff, S., U. Heyder, S. Ostberg, D. Gerten, and J. Heinke (2013), Contribution of permafrost soils to the global carbon budget, Environ. Res. Lett., 8, 014026, doi:10.1088/1748-9326/8/1/014026. 
Schirrmeister, L., C. Siegert, T. Kuznetsova, S. Kuzmina, A. A. Andreev, F. Kienast, H. Meyer, and A. Bobrov (2002), Paleoenvironmental and paleoclimatic records from permafrost deposits in the Arctic region of northern Siberia, Quat. Int., 89, 97-118, doi:10.1016/S1040-6182(01) 00083-0.

Schneider von Deimling, T., M. Meinshausen, A. Levermann, V. Huber, K. Frieler, D. M. Lawrence, and V. Brovkin (2012), Estimating the permafrost carbon feedback on global warming, Biogeosciences, 9, 649-665, doi:10.5194/bg-9-649-2012.

Schneider von Deimling, T., G. Grosse, J. Strauss, L. Schirrmeister, A. Morgaenstern, S. Schaphoff, M. Meinhausen, and J. Boike (2015), Observation-based modelling of permafrost carbon fluxes with accounting for deep carbon deposits and thermokarst activity, Biogeosciences, 12, 3469-3488, doi:10.5194/bg-12-3469-2015.

Schulze, E.-D., and M. Heimann (1998), Carbon and water exchange of terrestrial systems, in Asian Change in the Context of Global Climate Change, edited by J. Galloway and J. Melillo, pp. 145-161, Cambridge Univ. Press, Cambridge, U. K.

Schuur, E., J. Bockheim, J. Canadell, E. Euskirchen, C. Field, S. Goryachkin, S. Hagemann, P. Kuhry, P. Lafleur, and H. Lee (2008), Vulnerability of permafrost carbon to climate change: Implications for the global carbon cycle, BioScience, 58, 701-714.

Schuur, E. A. G., et al. (2011), High risk of permafrost thaw, Nature, 480, 32-33.

Schuur, E. A. G., et al. (2013), Expert assessment of potential permafrost carbon feedback to climate change, Clim. Change, 119, 359-374, doi:10.1007/s10584-013-0730-7.

Schuur, E. A. G., et al. (2015), Climate change and the permafrost carbon feedback, Nature, 520, 171-179, doi:10.1038/nature14338.

Serreze, M. C., and J. A. Francis (2006), The arctic amplification debate, Clim. Chang., 76, 241-264.

Sheffield, J., G. Goteti, and E. F. Wood (2006), Development of a 50-yr high-resolution global dataset of meteorological forcings for land surface modeling, J. Clim., 19, 3088-3111.

Sistla, S. A., J. C. Moore, R. T. Simpson, L. Gough, G. R. Shaver, and J. P. Schimel (2013), Long-term warming restructures arctic tundra without changing net soil carbon storage, Nature, 497, 615-618, doi:10.1038/nature12129.

Sitch, S., C. Huntingford, N. Gedney, P. E. Levy, M. Lomas, S. L. Piao, R. Betts, P. Ciais, P. Cox, and P. Friedlingstein (2008), Evaluation of the terrestrial carbon cycle, future plant geography and climate-carbon cycle feedbacks using five dynamic global vegetation models (DGVMs), Global Change Biol., 14, 2015-2039.

Slater, A. G., and D. M. Lawrence (2013), Diagnosing present and future permafrost from climate models, J. Clim., 26, 5608-5623, doi:10.1175/ BAMS-D-12-00121.1.

Smith, B., I. C. Prentice, and M. T. Sykes (2001), Representation of vegetation dynamics in modelling of terrestrial ecosystems: Comparing two contrasting approaches within European climate space, Glob. Ecol. Biogeogr., 10, 621-637.

Sokolov, A. P., D. W. Kicklighter, J. M. Melillo, B. S. Felzer, C. A. Schlosser, and T. W. Cronin (2008), Consequences of considering carbon-nitrogen interactions on the feedbacks between climate and the terrestrial carbon cycle, J. Clim., 21, 3776-3796.

Todd-Brown, K. E. O., et al. (2014), Changes in soil organic carbon storage predicted by Earth system models during the 21 st century, Biogeosciences, 11, 2341-2356, doi:10.5194/bg-11-2341-2014.

Treat, C., et al. (2015), A pan-Arctic synthesis of $\mathrm{CH}_{4}$ and $\mathrm{CO}_{2}$ production from anoxic soil incubations, Global Change Biol., 21, 2787-2803, doi: $10.1111 / \mathrm{gcb} .12875$.

Viovy, N., and P. Ciais (2011), CRUNCEP data set for 1901-2008, Tech. Rep. Version 4, Lab. des Sci. du Climat et de l'Environnement. [Available at http://dods.extra.cea.fr/data/p529viov/cruncep/.]

Wang, W., et al. (2016), Diagnostic and model dependent uncertainty of simulated Tibetan permafrost area, Cryosphere, 10, 287-306, doi:10.5194/tc-10-287-2016.

Wania, R., I. Ross, and I. C. Prentice (2009a), Integrating peatlands and permafrost into a dynamic global vegetation model: I. Evaluation and sensitivity of physical land surface processes, Global Biogeochem. Cycles, 23, GB3014, doi:10.1029/2008GB003412.

Wania, R., I. Ross, and I. C. Prentice (2009b), Integrating peatlands and permafrost into a dynamic global vegetation model: II. Evaluation and sensitivity of vegetation and carbon cycle processes, Global Biogeochem. Cycles, 23, GB3015, doi:10.1029/2008GB003413.

Wania, R., I. Ross, and I. C. Prentice (2010), Implementation and evaluation of a new methane model within a dynamic global vegetation model: LPJ-WhyMe v1.3.1, Geosci. Model Dev., 3, 565-584.

Watanabe, S., et al. (2011), MIROC-ESM 2010: Model description and basic results of CMIP5-20c3m experiments, Geosci. Model Dev., 4 , 845-872, doi:10.5194/gmd-4-845-2011.

Weedon, G. P., S. Gomes, P. Viterbo, W. J. Shuttleworth, E. Blyth, H. Österle, J. C. Adam, N. Bellouin, O. Boucher, and M. Best (2011), Creation of the WATCH forcing data and its use to assess global and regional reference crop evaporation over land during the twentieth century, J. Hydrometerol., 12, 823-848, doi:10.1175/2011JHM1369.1.

Willmott, C. J., and K. Matsuura (2001), Terrestrial Air Temperature and Precipitation: Monthly and Annual Time Series (1950-1999) (Version 1.02), Cent. for Clim. Res., Univ. of Delaware, Newark, Del. [Available at http://climate.geog.udel.edu/ climate/html_pages/archive.html.]

Yi, S., K. Manies, J. Harden, and A. D. McGuire (2009), Characteristics of organic soil in black spruce forests: Implications for the application of land surface and ecosystem models in cold regions, Geophys. Res. Lett., 36, L05501, doi:10.1029/2008GL037014.

Yi, S., A. D. McGuire, E. S. Kasischke, J. Harden, K. Manies, M. Mack, and M. Turetsky (2010), A dynamic organic soil biogeochemical model for simulating the effects of wildfire on soil environmental and carbon dynamics of black spruce forests, J. Geophys. Res., 115, G04015, doi:10.1029/2010JG001302.

Yuan, F.-M., S.-H. Yi, A. D. McGuire, K. D. Johnson, J.-J. Liang, J. W. Harden, E. Kasischke, and W. A. Kurz (2012), Assessment of historical boreal forest carbon dynamics in the Yukon River Basin: Relative roles of climate warming and fire regime changes, Ecol. Applications, 22, $2091-2109$.

Zhang, W., P. Miller, B. Smith, R. Wania, T. Koenik, and R. Döscher (2013), Tundra shrubification and tree-line advance amplify arctic climate warming results from an individual-based dynamic vegetation model, Environ. Res. Lett., 8, 034023, doi:10.1088/1748-9326/8/3/034023.

Zhuang, Q., A. D. McGuire, J. Harden, K. P. O'Neill, V. E. Romanovsky, and J. Yarie (2002), Modeling soil thermal and carbon dynamics of a fire chronosequence in interior Alaska, J. Geophys. Res., 107(D1), 8147, doi:10.1029/2001JD001244.

Zhuang, Q., J. M. Melillo, M. C. Sarofim, D. W. Kicklighter, A. D. McGuire, B. S. Felzer, A. Sokolov, R. G. Prinn, P. A. Steudler, and S. Hu (2006), CO 2 and $\mathrm{CH}_{4}$ exchanges between land ecosystems and the atmosphere in northern high latitudes over the 21st century, Geophys. Res. Lett., 22, L17403, doi:10.1029/2006GL026972.

Zhuang, Q., X. Zhu, Y. He, C. Prigent, J. M. Melillo, A. D. McGuire, R. G. Prinn, and D. W. Kicklighter (2015), Influence of changes in wetland inundation extent on net fluxes of carbon dioxide and methane in northern high latitudes from 1993 to 2004, Environ. Res. Lett., 10, 095009, doi:10.1088/1748-9326/10/9/095009.

Zimov, S. A., S. P. Davydov, G. M. Zimova, A. I. Davydova, E. A. G. Schuur, K. Dutta, and F. S. Chapin III (2006), Permafrost carbon: Stock and decomposability of a globally significant carbon pool, Geophys. Res. Lett., 33, L20502, doi:10.1029/2006GL027484. 